\title{
From Hierarchies to Markets: FedEx Drivers and the Work contract as Institutional Marker
}

Julia Tomassetti

Georgetown University Law Center, jlt106@law.georgetown.edu

This paper can be downloaded free of charge from:

https://scholarship.law.georgetown.edu/facpub/1386

http://ssrn.com/abstract=2515818

Lewis \& Clark L. Rev. (forthcoming)

This open-access article is brought to you by the Georgetown Law Library. Posted with permission of the author. Follow this and additional works at: https://scholarship.law.georgetown.edu/facpub

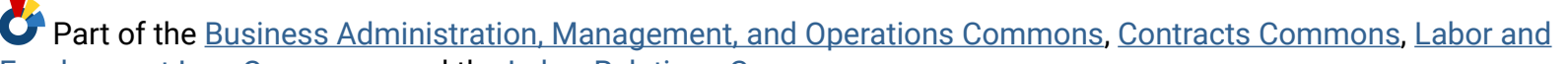
Employment Law Commons, and the Labor Relations Commons 
From HIERARCHIES TO MARKETS: FEDEX DRIVERS AND THE WORK

CONTRACT AS INSTITUTIONAL MARKER

\author{
Julia Tomassetti $^{*}$
}

Judges are often called upon today to determine whether certain workers are "employees" or "independent contractors." The distinction is important, because only employees have rights under most statutes regulating work, including wage and hour and antidiscrimination law. Too often judges exclude workers from statutory protection who resemble what scholars have described as "typical" employees-long-term, full-time workers with set wages and routinized responsibilities within a large firm. To explain how courts reach these counterintuitive results, the article examines recent decisions finding that FedEx delivery drivers are independent contractors rather than employees. The article finds that instability in the legal distinction between employees and independent contractors is embedded within the employment contract itself, in the law's attempt to construe the legal relations of master and servant as a "contract." By merging contractual formation and performance, this attempt creates two doctrinal ambiguities. By manipulating these ambiguities, the courts transformed some of the same vulnerabilities that place the drivers within the policy concerns of collective bargaining and wage and hour law into evidence of their autonomy. The courts also attempted to reconcile the awkward fit of master-servant authority and contract by constructing the written contract that drivers sign as an institutional marker of non-employment.

The attempt to encase master-servant authority in contract also destabilizes distinctions between firms and markets. The FedEx decisions marshal this instability to redefine a firm, as conceptualized by major economic theories of the firm, as a market. They conflate the de-personality of bureaucracy with the impersonality

\footnotetext{
* Jerome Hall Postdoctoral Fellow, University of Indiana Maurer School of Law, Center for Law, Society, \& Culture. Assistant Professor of Law, City University of Hong Kong (beginning 2016). Harvard Law, JD; UCLA, Sociology PhD. Noah Zatz and Maurice Zeitlin provided invaluable guidance on this project. I am also grateful to Anna Gelpern, Greg Klass, Naomi Mezey, Mike Seidman, Larry Solum, Katherine Stone, Robin West, Rabia Belt, and Sherally Munshi for their feedback.
} 
of the market. The drivers' fungibility as low-skilled workers performing standardized routines becomes evidence of their entrepreneurial opportunity, and the decisions submerged the FedEx bureaucracy beneath a nexus of contracts. The decisions reject theories of the firm that ground the legitimacy of the corporation in the production of goods and services. While we ultimately require a more radical transformation in work relations to prevent decision makers from redefining servitude as equality, the article recommends two provisional suggestions to improve decision-making in disputes over employment status.

\section{INTRODUCTION}

Most times when we receive a package delivery, whether it's from UPS, FedEx, or the Postal Service, it looks like the drivers are pretty much doing the same work. We track the package online or receive email updates regarding the delivery date. The doorbell rings. Outside is a deliveryman, neatly groomed, in uniform, and sporting an ID badge and the company logo. He is courteous as he hands you the package and perhaps requests your signature. As he turns to return to a recognizable truck, he says, "Have a nice day."

You might find it difficult to believe that, according to FedEx, its drivers are not employees, but independent contractors - even entrepreneurs. You might also find it difficult to believe that the employment status of FedEx drivers is a contested legal issue, and has been for decades.

The distinction between employees and independent contractors is important, because only employees have rights under most statutes regulating work, including wage and hour, antidiscrimination, and collective bargaining law. Only employers have obligations under these laws, such as paying unemployment insurance premiums or payroll taxes. ${ }^{1}$

FedEx classifies about 16,000 package and delivery drivers nationwide as independent contractors. Other drivers it classifies as

\footnotetext{
${ }^{1}$ See Noah Zatz, Working Beyond the Reach or Grasp of Employment Law, in THE Gloves-OFF ECONOMY: WORKPlace STANDARDS AT THE BOTTOM OF AMERICA's LABOR Market (Annette D Bernhardt, et al. eds., 2008); Katherine V.W. Stone, From WIDGETS TO DigITS (2004).
} 
employees of its independent contractors and not of FedEx. ${ }^{2}$ By relying on these classifications, FedEx has frustrated drivers' attempts to unionize under the National Labor Relations Act (NLRA) and to obtain relief under other law, including workers compensation and wage and hour legislation. While the work of UPS and FedEx drivers is nearly identical, the positions differ. UPS drivers are unionized. They earn about $\$ 60,000$ per year and have health insurance and other benefits. FedEx drivers earn about $\$ 25,000-\$ 35,000$ per year and have sparse benefits apart from annual vacation. ${ }^{3}$

Today, countless employers are re-organizing work to avoid the legal duties of an employment relationship. Many are recategorizing employees as independent contractors. Many are renouncing their legal identity as the "employer" of workers they control through subcontractors, subsidiaries, or other intermediaries. ${ }^{4}$ Disputes over employment status affect millions of workers and arise across a wide spectrum of work-from manufacturing to services, low skill to professional work, and the public to private sector. ${ }^{5}$ The re-organization of work costs state and federal treasur-

\footnotetext{
${ }^{2}$ FedEx Home Delivery v. NLRB (FHD), 563 F.3d 492, 495 (D.C. Cir. 2009) (4,000 FedEx Home division drivers); In re FedEx Ground Package Sys., No. 3:05-MD-527 RM, 2007 WL 3036891, at *2 (Oct. 12 2007) (12,000 FedEx Ground division drivers).

3 Steven Greenhouse, The Big Squeeze: Tough Times for the American WORKER 123 (2008). New York FedEx drivers earn about \$750 per week, for sixty-hour weeks and sparse benefits; UPS drivers earn about \$1,400 per week and receive benefits. Josh Kosman, Trucking Crazy! FedEx Guts Bill That Would Have Aided Drivers, N.Y. Post, Aug. 8, 2013, at 22, available at http://nypost.com/2013/08/10/trucking-crazyfedex-guts-bill-that-would-have-aided-drivers.

4 See David Weil, The Fissured Workplace (2014); Zatz, supra note _; Catherine Ruckelshuas, Rebecca Smith, Sarah Leberstein, \& Eunice Cho, Nat'L Employment LaW Project, Who's the Boss (2014) [hereinafter Who's the Boss?]; Lalith DeSilva, Adrian Millett, Dominic Rotondi, \& William Sullivan, PlanMatics, INDEPENDENT CONTRACTORS: PREVALENCE AND IMPLiCATIONS FOR Unemployment Insurance Programs (2000) [hereinafter Planmatics] (one of few studies with robust national data on extent of contingent employment). See also Catherine K. Ruckelshaus, National Employment Law Project, Leveling the Playing Field: Protecting Workers and Businesses AfFected By MisCLASSIFICATION (2010) (employers can save over 30\% on payroll costs by avoiding taxes through worker misclassification). For some purposes, firms prefer to classify workers as employees. Under the Copyright Act, only independent contractors by default have intellectual property rights in their creative works. See Cmty. for Creative Non-Violence v. Reid, 490 U.S. 730, 752 (1989). Also, workers compensation insurance does not cover injuries to independent contractors, putting firms at risk of tort liability. See, e.g., Carr v. FedEx Ground Package System, Inc., 733 S.E.2d 1 (Ga. Ct. App. 2012).

${ }^{5}$ See, e.g., David WeIL, The Fissured WorkPlace (2014).
} 
ies billions in tax revenue. It costs workers billions in wage theft and is a means by which firms drive down industry wages. ${ }^{6}$ The questions "who is an employee”?" and "who is an employer" have assumed global significance, particularly in places that tie social insurance and civil rights to employment. ${ }^{7}$

FedEx has litigated its drivers' employment status since the late 1980s. ${ }^{8}$ Several dozen lawsuits are pending today, including class actions from over thirty states. ${ }^{9}$ FedEx expends substantial resources litigating drivers' employment status, because the viability of its business model depends on avoiding the work law obligations faced by its main competitor, the unionized UPS. ${ }^{10}$ While most courts and agencies are finding the drivers to be employees, ${ }^{11}$

6 Who's the Boss; U.S. Gen. AcCounting OfFice, Contingent Workers: INCOMES AND BENEFITS LAG BEHIND THOSE OF REST OF WORKFORCE (2000).

7 See, e.g., Rethinking WorkPlace Regulation: Beyond the Standard Contract of Employment (Katherine V. W. Stone and H. W. Arthurs eds., 2013); The IDEA OF LABOUR LAW (Guy Davidov and Brian Langille eds., 2011).

${ }^{8}$ See, e.g., Roadway Package System, 292 N.L.R.B. No. 52 (1989). See also Jeffrey M. Hirsch, Employee or Entrepreneur? 68 WASH. \& LEE L. REV. 353 (2011); Micah P. S. Jost, Independent Contractors, Employees, and Entrepreneurialism Under the National Labor Relations Act: A Worker-by-Worker Approach, 68 WASH \& LEE L. REV. 311 (2011); Jamison F. Grella, From Corporate Express to FedEx Home Delivery: A New Hurdle for Employees Seeking the Protections of the National Labor Relations Act in the D.C. Circuit, 18 Am. U. J. Gender Soc. Pol'y \& L. 877 (2009); Todd D. Saveland, FedEx's New Employees: Their Disgruntled Independent Contractors, 36 TRANSP. L.J. 95 (2009).

${ }^{9}$ Anna Kwidzinski, Ninth Cir. Says FedEx Drivers in Two States Are Employees, Not Independent Contractors, Aug. 28, 2014, 12 WLR 1443 [BNA]; GREENHOUSE, supra note _, at 123.

10 Anya Litvak, FedEx Ground Makes Change to Independent Contractor Model, Pittsburgh Bus. Times, June 10, http://www.bizjournals.com/pittsburgh/stories/2010/ 06/14/story4.html?page=all; FedEx's air-freight division classifies its workers as employees; however, in 1996 the company successfully lobbied Congress (including by giving many Congresspersons rides in its jets) to put its drivers under the jurisdiction of the Railway Labor Act (RLA) rather than the NLRA, which would require all 40,000 drivers dispersed across the country to organize in one national unit, making it very difficult to organize a union. GREENHOUSE, supra note _, at 122; Neil A. Lewis, A Lobby Effort That Delivers The Big Votes; Federal Express Knows Its Way Around Capital, N.Y. TIMES, Oct. 12, 1996, available at 1996 WLNR 4407778. By one estimate, FedEx has saved up to $\$ 400$ million per year by classifying its drivers as independent contractors. GREENHOUSE, supra note _.

11 See, e.g., In re FedEx Ground Package Sys., Inc., No. 10-3115, 2015 WL 4099853 (7th Cir. July 8, 2015); Carlson v. FedEx Ground Package Systems, Inc., 787 F.3d 1313 (11 $1^{\text {th }}$ Cir. 2015); Alexander v. FedEx Ground Package Sys., 765 F.3d 981 (9th Cir. 2014); Slayman v. FedEx Ground Package Sys., 765 F.3d 1033 (9th Cir. 2014); Wells v. FedEx Ground Package Sys., 979 F.Supp.2d 1006 *9, 17 (E.D. Mo. 2013); Schwann v. FedEx Ground Package Sys., No. 11-11094-RGS, 2013 WL 3353776 (D. 
important decisions deeming the drivers to be independent contractors still stand. ${ }^{12}$

Most statutes and administrative guidelines fail to define employee or employer in any helpful matter. ${ }^{13}$ This has left the issue of employment status largely in the hands of adjudicators, ${ }^{14}$ on the courts and the National Labor Relations Board, the agency that enforces the NLRA. Judges apply common law standards and make decisions on a case-by-case basis. The resulting case law is notoriously inconsistent as to who is, and who is not, in an employment relationship. ${ }^{15}$ Further, judges have excluded many workers from statutory protection who fit squarely within the policy concerns of the law. ${ }^{16}$

Mass. July 3, 2013), overturned in part, 2015 WL 501512 (2015); Estrada v. FedEx Ground, No. BC 210310, 2004 WL 5631425 (Cal. Super. Ct. July 26, 2004), aff'd, Estrada v. FedEx Ground Package Sys., 64 Cal. Rptr. 3d 327 (Ct. App. 2007); Craig v. FedEx Ground Package Sys., Inc., 335 P.3d 66 (Kan. 2014); FedEx Home Delivery, 361 N.L.R.B. No. 55, 2014 WL 4926198 (2014).

${ }^{12}$ FHD, 563 F.3d 492; In re FedEx Ground Package Sys. (Kansas decision), 734 F.Supp.2d 557 (N.D. Ind. 2010), rev'd, In re FedEx Ground Package Sys., Inc., No. 1031152015 WL 4099853 (7th Cir. July 8, 2015); In re FedEx Ground Package Sys. (Multi-state decision), 758 F.Supp.2d 638 (N.D. Ind. 2010), rev'd in part, Alexander v. FedEx Ground Package Sys., 765 F.3d 981 (9th Cir. 2014), Slayman v. FedEx Ground Package Sys., 765 F.3d 1033 (9th Cir. 2014), and Carlson v. FedEx Ground Package Systems, Inc., 787 F.3d 1313 (11th Cir. 2015). benefit

${ }^{13}$ See, e.g., 29 U.S.C. § 1002(6) (defining “employee” for purposes of employee plans). See also Richard R. Carlson, Why the Law Still Can't Tell an Employee When It Sees One and How It Ought to Stop Trying, 22 BERKELEY J. EMP. \& LAB. L. 295 (2001).

${ }^{14}$ Hereafter, "judges” refers to adjudicators on administrative agencies and courts.

15 See Katherine V.W. Stone, Legal Protections for Atypical Employees: Employment Law for Workers Without Workplaces and Employees with Employers, 27

BERKELEY J. EMP. \& LAB. L. 251, 260 (2006); Carlson, supra note _, at 298-301, 338.

16 See, e.g., SARAh Leberstein, Nat'L Employment LaW Project, IndePEndent CONTRACTOR Misclassification IMPOSES Huge COSTS ON WORKERS AND FEDERAL AND StATE TREASURIES (2012) (summarizing twenty state-level studies of scope and costs of independent contractor misclassification); U.S. Gov. ACCOUNTABILITY OfFICE, EMPLOYEe Misclassification: IMPROVEd COORDINATION, OUTREACH, AND TARGETING Could Better Ensure Detection and Prevention (2009); American Rights at Work, The Haves and the Have-Nots: How American Labor LaW Denies a QuARTER of THE WorkForce COLLECTIVE BARgaining Rights (2008); EMPLOYMENT Dev. Dep't, State of Cal., Annual Report: Fraud Deterrence and Detection ACTIVITIES (2008), available at http://www.edd.ca.gov/pdf_pub_ctr/report2008.pdf; JoHN Petro, Drum Major Institute, The Road to Nowhere: How the Misclassification of Truck Drivers Hurts Workers, Job Quality, and New York State (2012); Massachusetts Department of LABOR, Joint TASK ForCe on the Underground ECONOMY AND EMPLOYEE MiSClASSIFICATION, ANNUAL REPORT (2010). 
Two federal courts recently upheld FedEx's labeling of its delivery drivers as independent contractors. ${ }^{17}$ The first was the D.C. Circuit, the most powerful appellate court in the United States. In 2009, in the case of FedEx Home Delivery (FHD) it granted summary judgment to FedEx, finding that drivers who had voted to unionize had no right to do so, because they were not employees. ${ }^{18}$ The other is a district court in Indiana, where class actions by FedEx drivers from over 30 states were consolidated in historic, multidistrict litigation. The drivers were suing FedEx primarily for fraud, wage and hour violations, and workers compensation. ${ }^{19}$ The multi-district decisions on the drivers' employment status have been overturned in a few states (by every court that has reviewed them thus far), ${ }^{20}$ but FHD remains intact. ${ }^{21}$

The central question of this paper is, how was it possible for courts finding the drivers to be independent contractors to reach these counterintuitive results? By examining this question, the paper penetrates broader questions about the legal identity of employment: what accounts for the well-known inconsistency in the case law on employment status? How are judges able to find that workers who are clearly within the policy scope of workplace regulation are excluded as independent contractors? How do judges transform what scholars have described as "standard" employment into "independent entrepreneurialism"? The paper does not offer a doctrinal solution to the question of employment status. Rather, it offers a new theory of what allows judges to reach inconsistent and policy-defeating results in the first instance.

\footnotetext{
${ }^{17}$ FHD, 563 F.3d 492; Kansas decision, 734 F.Supp.2d 557; Multi-state decision, 758 F.Supp.2d 638.

${ }^{18}$ FHD, 563 F.3d 492.

${ }^{19}$ Kansas decision, 734 F.Supp.2d 557; Multi-state decision, 758 F.Supp.2d 638.

20 The Seventh, Ninth, and Eleventh Circuits (the latter following the Kansas Supreme Court) reversed Judge Miller's Kansas decision and Multi-state decision for drivers in their jurisdictions. In re FedEx Ground Package Sys., Inc., No. 10-3115, 2015 WL 4099853 (7th Cir. July 8, 2015); Alexander v. FedEx Ground Package Sys., 765 F.3d 981 (9th Cir. 2014); Slayman v. FedEx Ground Package Sys., 765 F.3d 1033 (9th Cir. 2014); Carlson v. FedEx Ground Package Systems, Inc., 787 F.3d 1313 (11 ${ }^{\text {th }}$ Cir. 2015); Craig v. FedEx Ground Package Sys., Inc., 335 P.3d 66 (Kan. 2014).

${ }^{21}$ A broad regime of federal preemption in labor law makes FHD all the more important. See Cynthia L. Estlund, The Ossification of American Labor Law, 102 COLUM. L. REV. 1527, 1530-31, 1569-79 (2002) (discussing federal preemption of labor law).
} 
The problem is more deep-seated than others have surmised. Other legal scholars tend to attribute inconsistency and statutory exclusion in the case law to a decline in industrial work since the 1970s or to imprecision in the legal tests for employment status. Neither of these accounts can explain the FedEx cases: the drivers resemble what scholars and judges have referred to as "standard" or "industrial" employees-fulltime, long-term workers with set wages and pre-defined, routinized duties within a large firm. ${ }^{22}$ Further, many of the features that are evidence of employment status under the legal tests are present in the drivers' relationship. Where judges disagree is on their legal meaning.

This paper shows that instability in the legal distinction between employment and non-employment is rooted in the employment contract itself, in its attempt to construe the legal relations of master and servant as a "contract." The attempt to fit employment in the framework of contract creates two doctrinal ambiguities that make the dominant standard for distinguishing employment from independent contracting relationships — the means-end standardirresolvable.

The means-ends standard looks to the extent of the alleged employer's right to control the work. An employer has a right to control the "means" of the work, not only the "ends" of the work. The major tests for employment status ask judges to consider a long, open-ended list of factors to determine whether the alleged employer controls the means of the work, like the extent of supervision and whether the alleged employer has a right to assign daily work. ${ }^{23}$

The fusion of master-servant authority and contract make the means-end question irresolvable by blurring contractual formation and performance. Parties to an employment relationship do not consummate a contractual bargain through an exchange of promises, or through an exchange of a promise for performance, and later move onto the business of carrying out the agreement. Employment entails a continuing renewal of offer and acceptance through an exchange of performances.

First, the employment contract makes ambiguous the activities of bargaining over the work and carrying out the work, or produc-

\footnotetext{
${ }^{22}$ See infra Part I.B.

${ }^{23}$ See infra Part I.A.
} 
ing. Employee and employer bargain as they produce goods or services: the employer bargains over the terms of work by directing the work, and the employee accepts these contractual offers by following the employer's direction each moment the employee works without quitting. The means-ends standard, however, depends on being able to distinguish when the parties are bargaining from when they are producing. It may look like one party is controlling the work, for example, but if the parties are still negotiating, then one party may be getting its way by driving a hard bargain, not because it is an employer. The employment contract in practice merges independence in negotiating the "ends" of the work with obedience in producing, the "means" of the work.

The second ambiguity surfaces in attempts to interpret a written work agreement in disputes over employment status, rather than in distinguishing the activities of bargaining from producing. It is the ambiguity between contractual duties and the manner of performing them. The means-ends standard depicts employment as a contract, but a special kind of contract-it gives one party a right to determine how the other party carries out its contractual obligations. In other contracts, the parties commit one another only to the "ends" of the deal; neither has a right to dictate how the other party satisfies these ends. The employment contract, however, gives one this right: the employer has a right to control the "means" of the work. The means-ends standard depends on being able to distinguish between contractual duties and the manner of their performance, in order to evaluate whether one party is controlling the latter or only the former. The problem is, again, that the fusion of master-servant authority with contract makes the distinction illusory. The employer and employee determine "contractual” duties as they produce.

This conundrum puts a written agreement in an ambiguous position in employment status disputes. Courts disagree as to what extent, if at all, the alleged employer controls its workers when it relies on a written contract to direct the work: Does any term appearing in a written agreement, by virtue of its expression in something labeled an "agreement" or "contract," state a contractual end? If the alleged employer is not telling workers to do anything not in the contract, is it not controlling the work? By contrast, might some provisions of the contract describe how contractual ends are to be performed? 
Using the decisions finding FedEx drivers to be independent contractors (the "IC decisions"), this paper shows that the attempt to fuse master-servant authority and contract enables courts to transform employees into entrepreneurs. The IC decisions marshaled the doctrinal ambiguities embedded within the employment contract to redefine nearly all of the factors probative of employment status under the legal tests as evidence consistent with, if not evidence of, independent contracting. They engaged the ambiguities to transform features of the drivers' work that were typical of industrial employment into evidence of entrepreneurial opportunity. In the IC decisions, delivery route assignments, daily package assignments, supervision, discipline, promotions, shift replacements, training, the unskilled nature of the work, job duration, quasi-at-will authority, schedule controls, and work rules involving driving, appearance, customer interaction, and package handling became either irrelevant to the drivers' employment status or affirmative evidence that the drivers were independent businesspersons.

The FedEx disputes not only reveal the law's role in destabilizing the conventional boundaries of work relations, but also in reconstituting them. As part of the employment contract itself, the ambiguities between bargaining and producing, and between contractual duties and their performance, permit no doctrinal resolution. Stability in the legal identity of contemporary work relations depends on how we institutionalize them.

To institutionalize something is to construct it as a pattern of organizations, activities, norms, roles, and media. ${ }^{24}$ This pattern is historically specific, but tends to be durable and taken-for-granted. The elements of this pattern are institutional markers, features that signal a relationship is of one particular type and not another. ${ }^{25}$

The law plays a special role in institutionalization. Judges look to what are ostensibly extra-legal data points to impart meaning to legal categories, and organizations adjust their practices to mimic legal categories. Organizational practice provides the doctrinal categories with content that makes them recognizable, and meaning-

\footnotetext{
${ }^{24}$ See Viviana Zelizer, The Purchase of Intimacy (2005).

${ }^{25}$ See also Noah Zatz, Working at the Boundaries of Markets: Prison Labor and the Economic Dimension of Employment Relationships, 61 VAND. L. R. 857 (2008) [hereinafter Zatz, Working at the Boundaries].
} 
ful, as social relations. At the same time, the law confers legitimacy on organizational practices when it recognizes them as valid legal categories. ${ }^{26}$

While the tension within employment between master-servant authority and contract has always been there, it surfaces in times of institutional disruption. The dominant institutional résumé of employment in the $20^{\text {th }}$ century, in terms of political and cultural salience, was industrial employment. Employment was a long-term, full-time, direct relationship between a large firm and a worker with set wages and pre-defined duties. The institution of industrial employment submerged, for a time and in certain places, the contradictory complex of servitude and equality that defines employment. It did not resolve it. Today, the growing service sector, revolutions in logistics and communications technology, financialization, and other developments are disrupting the institutional order of industrial work. As courts contend with the doctrinal manifestations of this disruption, they also work to re-institutionalize employment.

The IC decisions seek to re-institutionalize what looks much like industrial employment-a direct, full-time, long-term relationship between a worker and a large firm-as one of independent entrepreneurialism. The paper explores two ways in which the decisions construct the drivers' written work agreement with FedEx as an institutional marker of non-employment.

As they re-institutionalize contemporary work relations, judges also redefine the institutional contours of firms and markets. The paper draws on economic theory regarding the institutional structures for directing and coordinating resources in production. Firm theorists, like Ronald Coase and Oliver Williamson, ${ }^{27}$ have attempted to explain why firms exist as an alternative to markets for organizing production, and to account for their bordering. The familiar iteration of the question is, "what determines whether a firm 'makes' an input to production or instead 'buys' an input to pro-

${ }^{26}$ Lauren Edelman, et al., When Organizations Rule: Judicial Deference to Institutionalized Employment Structures, 117 AM. J. of Soc. 888 (2011).

${ }^{27}$ E.g., Ronald Coase, The Nature of the Firm, 4 Economica 386 (1937); Oliver Williamson, Transaction-Cost Economics: The Governance of Contractual Relations, 22 J. L. \& Econ. 233 (1979) [hereinafter Williamson, Governance]; Oliver Williamson, The Economics of Organization: The Transaction Cost Approach, 87 Am. J. Soc. 548 (1981) [hereinafter Williamson, Economics]. 
duction?" Economic theories of the firm tend to associate firms and markets with different legal relations: market transactions with contract and firm transactions with property rights or employment. ${ }^{28}$ Theories of the firm have even suggested that employment and independent contracting are homologous with firms and markets. $^{29}$

Due to the close relationship between employment and sociolegal conceptions of the business form, the law's attempt to construe employment as a contract tends to destabilize boundaries between firms and markets just as it destabilizes boundaries between employment and non-employment. In the IC decisions, the ambiguity between bargaining and producing in employment reappears as a tension within the firm: employment as a contract is a direct and bilateral relationship between putatively equal parties; however, employment is also a legal rationale for a firm's centralized control over indirect, hierarchical, and multilateral relations in production. The contradiction between master-servant authority and contract enabled FedEx and the courts to submerge the consummate firm - the Weberian bureaucracy - beneath a nexus of contracts.

Despite the indeterminacy of the legal tests for employment status, the IC decisions are troubling for reasons of doctrine, policy, and political legitimacy. First, they ignore-and thus answer incorrectly - what is arguably the underlying query in a dispute over whether a work relationship is employment or independent contracting: is the relationship more like a contract or more like a master-servant relationship? Secondly, in ignoring this question, the IC decisions thwart the policy concerns of the law with protecting persons who sell their ability to work to make a living. The decisions transform some of the same vulnerabilities that place the drivers within the policy concerns of minimum wage and collective bargaining law into evidence of their autonomy! The more the workers appear as interchangeable cogs in a machine, the more they look like independent entrepreneurs in the courts' reasoning. The decisions conflate the depersonality of bureaucracy with the impersonality of the market. Third, the IC decisions redefine the

\footnotetext{
${ }^{28}$ See infra Part IV.B.

${ }^{29}$ See infra Part IV.B.
} 
normative relationship between the corporate form and the productive enterprise.

The paper proceeds as follows. Part I summarizes the legal tests for employment status and examines the primary explanations for instability in the legal identity of employment in the case law. Part II is the theoretical core of the argument. It shows that the law's attempt to render employment a contract produces two doctrinal ambiguities in employment status disputes. Part III illustrates the first doctrinal ambiguity at work. It shows how the IC decisions drew on the ambiguity between bargaining and producing to reinterpret traditional institutional markers of employment and construct the written document drivers sign as an institutional marker of non-employment. It also shows that their interpretation formed an axis of disagreement among courts considering the employment status of FedEx drivers. Part III also critiques how the IC decisions resolved the ambiguity on doctrinal and policy grounds. Part IV discusses the relationship between employment and economic theories of the firm. It shows that the law's attempt to fit employment in the legal framework of contract destabilizes classic conceptions of firms and markets. It also shows that, in transforming the FedEx drivers into independent contractors, the IC decisions transform a firm, as conceptualized by major theories of the firm, into a market. They likewise conceal a highly rational bureaucracy under a nexus of contracts. Part IV critiques the IC decisions for thwarting the policy objectives of work law and hollowing out the normative basis of the business form. Part V illustrates the second ambiguity created by the fusion of master-servant authority and contract in the IC decisions. It analyzes and critiques the courts' institutional work to construct the written document signed by drivers as a marker of non-employment.

The conclusion suggests two provisional strategies to improve decision-making in disputes over employment status. The first is in the judicial repertoire: use contract law to evaluate whether the disputed work arrangement is more like a contract or more like a master-servant relationship. The second proposal is to use classic theories of the firm to distinguish between entrepreneurial opportunity - opportunity conferred by the market - and an employee's opportunity within a firm.

Nonetheless, because legal ambiguity in contemporary work relations is based on a contradiction at the heart of the employment 
contract-a contradiction between contractual equality and servitude- the article concludes that doctrinal adjustments will not resolve the problem. Only a radical transformation in work relations will stabilize the legal identity of work relations and prevent decision-makers from redefining relations of subordination as relations of equality.

\section{EMPLOYMENT STATUS}

\section{A. The Legal Tests}

The definition of the employment contract is working for another, under the other's right of control. ${ }^{30}$ The dominant expression of this definition as a legal standard is the means-ends standard. Courts ask, does the alleged employer control only the "ends" of the work or does it also control the "means" of the work? ${ }^{31}$

Most statutes do not include their own definition of employment, so courts and agencies are largely responsible for constructing the employment relationship out of this definition and standard. Almost all of the tests for employment status under state, federal, and local law are variations of two, overlapping tests: the common law master-servant agency test ${ }^{32}$ and the economic realities test. ${ }^{33}$

${ }^{30}$ E.g., Kelley v. S. Pacific Co., 419 U.S. 318 (1974).

${ }^{31}$ Local 777 1978, 897, quoting Party Cab 1949, 92.

32 The federal agency test governs claims under ERISA, the NLRA, Title VII, ADA, ADEA, OSHA, the Copyright Act, and whenever a statute does not provide a constructive definition of employment. Nationwide Mut. Ins. Co. v. Darden, 503 U.S. 318 (1992); Community for Creative Non-Violence v. Reid, 490 U.S. 730 (1989); Clackamas Gastroenterology Assoc.s v. Wells, 538 U.S. 440 (2003).

33 The economic realities test governs cases under the FLSA, Migrant Workers and Agricultural Workers Protection Act (MWAWPA), Family Medical Leave Act (FMLA), and many state wage and hour laws. The economic realities test includes many agency test factors. The central differences are that the former asks whether the worker is "economically dependent" on the alleged employer and allows courts to consider statutory purpose. Cf. Darden, 503 U.S. 318; NLRB v. Town \& Country Electric, Inc., 516 U.S. 85, 91-92 (1995). The Supreme Court intended the test to be broader than the agency test. Darden, 503 U.S. at _; Rutherford Food Corp. v. McComb, 331 U.S. 722, 725; Hearst, 322 U.S. at 127; Zheng v. Liberty Apparel Co., 355 F.3d 61, 70 (2d Cir. 2003). See also Bruce Goldstein, et al., Enforcing Fair Labor Standards in the Modern American Sweatshop: Rediscovering the Statutory Definition of Employment, 46 UCLA L. REV. 983 (1998); Marc Linder, Towards Universal Worker Coverage under the National Labor Relations Act: Making Room for Uncontrolled Employees, Dependent Contractors, and Employee-Like Persons, 66 U. DET. L. REV. 555 (1988). Whether in practice courts interpret employment more broadly under the economic realities test is subject to dispute. 
Under the federal tests, and under most state versions, judges consider an open-ended list of indicia as evidence bearing on the control question or as secondary evidence of employment status. The Restatement (2nd) of Agency, an influential secondary summary of the common law, lists several factors:

(a) the extent of control which, by the agreement, the master may exercise over the details of the work;

(b) whether or not the one employed is engaged in a distinct occupation or business;

(c) the kind of occupation, with reference to whether, in the locality, the work is usually done under the direction of the employer or by a specialist without supervision;

(d) the skill required in the particular occupation;

(e) whether the employer or the workman supplies the instrumentalities, tools, and the place of work for the person doing the work;

(f) the length of time for which the person is employed;

(g) the method of payment, whether by the time or by the job;

(h) whether or not the work is a part of the regular business of the employer;

(i) whether or not the parties believe they are creating the relation of master and servant; and

(j) whether the principal is or is not in business. ${ }^{34}$

Additional factors that judges tend to consider include whether the worker works exclusively for the alleged employer or also services other clients; whether the worker conducts business in its own name; whether the work presents opportunities for entrepreneurial gain and loss; the extent of supervision; whether the alleged employer provides training; whether the worker is subject to discipline; whether the worker has the right to quit; whether the alleged employer can terminate the worker; whether the worker can turn

Linder, Dependent and Independent Contractors, supra note _; Benjamin F. Burry, Testing Economic Reality: FLSA and Title VII Protection for Workfare Participants, 2009 Univ. Chic. Leg. Forum 561 (2009); J.F. Harris, Worker Unity and the Law: A Comparative Analysis of the National Labor Relations Act and the Fair Labor Standards Act, and the Hope for the NLRA's Future, 13 N.Y. City L. Rev. 107 (2009).

${ }^{34}$ Restatement (SECOND) OF AgEnCy § 220(2) (1958). 
down assignments and whether the alleged employer can assign additional assignments; and whether the alleged employer assigns daily work. Courts also consider whether the alleged employer provides benefits or withholds payroll taxes. ${ }^{35}$

\section{B. Other Explanations}

There are two primary explanations for why "the law can't tell an employee when it sees one" 36 : imprecision in the legal tests for employment and a decline in industrial employment.

\section{Decline of Standard, Industrial Employment}

One explanation for the widespread disagreement among judges regarding the identity of employment is the disappearance of industrial work models around which the legal standards for employment status were conceived. The industrial model of work, or Fordism, involved a long-term, direct relationship between a worker with routinized responsibilities and a hierarchical, vertically integrated firm. The firm produced and traded in its own name and paid a family wage. ${ }^{37}$ Scholars suggest that, because the law was modeled on this "standard" employment relationship, it has difficulty apprehending post-industrial work. Many post-industrial relationships, like temporary agency work, part-time work, subcontracting, and networked production, are not characterized by the long-term, direct attachment of an employee to a single firm. ${ }^{38}$ The argument is that work is changing, but the law is not.

${ }^{35}$ E.g., Darden, 503 U.S. at 323; Community for Creative Non-Violence v. Reid, 490 U.S. 730, 751-52; Aymes v. Bonelli, 980 F.2d 857 (2d Cir. 1992).

${ }^{36}$ Richard R. Carlson, Why the Law Still Can't Tell an Employee When It Sees One and How It Ought to Stop Trying, 22 Berkeley J. Emp. \& Lab. L. 295 (2001).

${ }^{37}$ See Antonio Gramsci, Americanism and Fordism, in PRISON NoteBOOKS 286 (1971); StONE, WIDGETS, supra note _. Fordism also refers to a post-WWII regime of accumulation, or the particular relationship between production and consumption that was possible because many large industrial firms paid a family or living wage. The eponym of "Fordism" is Henry Ford, who famously introduced the \$5 wage so that every Ford Motor worker could afford to purchase a Ford automobile.

${ }^{38}$ STONE, WIDGETS, supra note _. 


\section{Legal Imprecision}

Another explanation for the inability of judges to agree on employment status is imprecision in the legal tests. ${ }^{39}$ For purposes of most statutes regulating employment, judges must consider a long, non-exclusive list of factors to determine employment status. Courts disagree on how many are necessary and which ones in what combinations are the most important. Standards that define employment by open-ended enumeration necessarily lead to inconsistent results like reading tealeaves. Further, the means-end standard is amenable to nearly infinite manipulation. Courts can always find some residual discretion left to the putative contractor, and they can describe the "ends" at the level of detail necessary for the employer to maintain complete control. ${ }^{40}$

\section{A Challenge}

The FedEx disputes challenge these explanations. The drivers' work relationship fits what scholars have referred to as standard, industrial employment-a long-term, full-time, direct relationship between a worker and large firm that trades and produces under a coherent business identity. The drivers have routinized responsibilities in an integrated production process, and they work under hierarchical, centralized management. Drivers must work 9 or 9.5 to 11 hours of work per day, five-days a week. Drivers must wear uniforms and punch in and out of work. They are subject to a system of supervision, performance evaluation, and discipline, all of which managers document in personnel files. They receive annual vacation, and performance bonuses. Most drivers work for FedEx for many years.

Almost all of the other features that are evidence of employment status under the legal tests are also present in the drivers' relationship: FedEx provides all of the tools of work, with the excep-

\footnotetext{
${ }^{39}$ E.g., id. (arguing that no factor on its own is reliable evidence of employment).

${ }^{40}$ One judge parodied the means-ends inquiry as follows: "Thus laborers are employed to empty a carload of coal. The employer insists that he does not control them, that he did not hire their 'services' but only contracted for the 'result,' an empty car. The means of unloading, he says, are their own, i.e., they can shovel right-handed or lefthanded, start at one end of the car or the other.” Powell v. Appeal Bd. of Mich. Employment Sec. Commission, 345 Mich. 455, 472 (1956) (dissent) (internal citations omitted).
} 
tion of the trucks, which drivers must purchase. FedEx decides which trucks are acceptable and their specifications, down to the shelving dimensions and material and acceptable brands of white paint. FedEx restricts drivers' ability to use the trucks for nonwork purposes. The work is unskilled, and FedEx trains drivers in its service procedures. The work is part of FedEx's regular and core business. Drivers' pay is based primarily on the hours they work. FedEx assigns mandatory tasks on a daily basis. Drivers must follow extensive rules on driving, personal appearance, vehicle appearance, handling packages, and interacting with FedEx customers. Drivers have one customer-they sell their delivery services only to FedEx. Drivers who perform exactly the same work (FedEx drivers employed by a temp agency) ${ }^{41}$ or very similar work are employees. The latter include drivers for FedEx's main competitors, UPS and DHS, and drivers for the company division FedEx Express.

Based on the main accounts for instability in the legal identity of employment, FedEx drivers should not be a hard case. However, the different case outcomes are not a product of disagreement regarding how to count, weigh, and balance a bevy of pro and con features under the legal tests. The D.C. Circuit and Judge Miller acknowledged that many factors probative of employment under the governing tests were present. They reinterpreted this evidence as evidence consistent with, or evidence of, non-employment.

\section{Construing Master-Servant Authority As “CONTRACT”}

\section{A. History of the Employment Contract}

The employment contract-working for another under the right of control of the other-is a product of the 19th century combination of the legal relationship between master and servant with the legal relationship of contract. Judges and treatise writers reconfig-

${ }^{41}$ In some of the FedEx cases, drivers could choose to become FedEx drivers as the formal employees of a temp agency that contracted with FedEx rather than as a FedEx contractor. Drivers underwent the same training and performed the same work whether hired as contractors or temporary employees. FedEx Home Delivery, Nos. 1-RC-22034, 1-RC-22035, 2006 NLRB Reg. Dir. Dec. LEXIS 264 at 20, 25, 40, $53-54$ (Sept. 20, 2006), vacated, 563 F.3d 492 (D.C. Cir. 2009). [hereinafter FHD NLRB Reg. Dir. decision 2006]. 
ured the master's property-like right to the servant's labor services as a right based in contract, a doctrine enabling parties to reach enforceable agreements in commodity exchanges. As they transferred the legal rationale for subordination to contract, courts expanded master-servant authority to cover a wide range of work relationships in which workers were not previously subject to this authority. With the development of larger-scale production, judges expanded master-servant agency authority to cover not just the right to direct a single worker or group of workers in a shop, but to justify managerial coordination and direction of the enterprise. ${ }^{42}$

Karl Marx suggested that, in the remarkable creation of value that occurred through the capitalist's purchase of labor power and the process of converting labor power into labor, the "laws that regulate the exchange of commodities have been in no way violated." 43 He was, perhaps, too cavalier. Employment is not a contract, and the attempt to fit employment in the legal framework of contract produces intractable problems of interpretation.

\section{B. Fitting Employment into Contract}

\section{The Problem of Consideration}

To see why it is so difficult to construe employment as a contract, first, take the issue of at-will employment, and the contractual requirements of consideration and mutual assent. Recall that the definition of employment is an agreement to work for another, under the other's right of control. By default, employment is atwill. ${ }^{44}$ Subject to limited exceptions, either party may terminate the relationship at any time, for a good reason, bad reason, or no rea-

42 Christopher Tomlins, Law, Labor, And IdeOlogy in the EARly AMERICAN Republic (1993); Robert J. Steinfeld, The InVention of Free Labor: The EMPlOYMENT RELATION IN ENGLiSH AND AMERICAN LAW AND CUltuRE, 1350-1870 (1991).

${ }^{43}$ Karl Marx, Capital, in Karl Marx: Selected Writings 452, 505 (2d ed., David McClellan ed., Oxford Univ. Press 2005) (1867).

${ }^{44}$ As contractual defaults go, the at-will default is particularly stubborn. Even when evidence discloses clear party intent to contract out of the at-will default, courts tend to be resistant to enforcing the term or permanent employment contracts. See e.g., Asmus v. Pacific Bell, 999 P.2d 71 (Cal. 2000). 
son. ${ }^{45}$ Enforceable contracts generally require consideration-a bargained for promise or performance in return for a promise. The option of the return promise is unavailable in at-will employment: the employee agrees follow the employer's commands so long as she feels like it. The employer agrees to provide work in exchange for pay so long as she feels like it. This is a quintessential case of illusory consideration. Neither party commits with a promise. ${ }^{46}$

Therefore, the employee provides consideration through performance. The employee "assents" to the employer's "offer" of work by following the employer's directions in the course of the work. Likewise, the employer makes a contractual offer by directing the employee in the work. If employment is a contract, it involves a continuing renewal of offer and acceptance at each moment the employee works under the employer's direction. ${ }^{47}$ The employee bargains over the terms and conditions of work by satisfactorily following the employer's instructions. The employer bargains as it directs the work, for instance, now telling the employee to work faster, now to perform additional work, now to stay late. Thus, in employment, the parties bargain and perform their deal at the same time. Employment is not a unilateral contract, however, in which one provides consideration for the promise through performance. Both employee and employer exchange performances,

45 The only limits on the employer's authority to terminate an employee are the carve-outs provided by statute and a handful of judicially created public policy exceptions. Statutory exceptions include, for instance, the prohibition in Title VII against terminating employees on the basis of race, color, national origin, religion, or gender. Public policy exceptions often restrict employers for terminating employees who refuse to commit perjury or who miss work for jury duty. See Katherine V.W. Stone, Dismissal Law in the United States: The Past and Present of At-Will Employment, in INTERNATIONAL COLLABORATIVE ON SOCIAL EUROPE (2007), available at http://papers.ssrn.com/abstract=1342667.

${ }^{46}$ C.f. Petroleum Refractionating Corp. v. Kendrick Oil Co., 65 F.2d 997, 999 (10th Cir. 1933).

${ }^{47}$ See also John R. Commons, Legal Foundations of CAPitalism 285 (1924) ("The labor contract is therefore not a contract, it is a continuing implied renewal of contracts at every minute and every hour, based on the continuance of what is deemed, on the employer's side, to be satisfactory service, and, on the laborer's side, what is deemed to be satisfactory conditions and compensation”; Armen A. Alchian and Harold Demsetz, Production, Information Costs, and Economic Organization, 62 AM. ECON. REV. 777 (1972). 
not a promise for a performance. They bargain and they produce at the same time. ${ }^{48}$

To further understand, consider that, by definition, the employee does not provide labor for pay through employment: employment is an agreement to work for another, to provide labor effort. (An agreement to exchange consummated work, labor, is an independent contracting agreement.) Based on the very nature of labor effort and the contractual requirement of assent, the parties cannot use contract to exchange labor effort: An employer cannot direct the employee's labor effort without the latter's ongoing assent. ${ }^{49}$ This is why a lease theory of employment does not ease the fit of employment in the Procrustean bed of contract. Hiring an employee in some ways looks like renting an asset capable of producing value-the employer leases the worker's ability to labor. A lessee has a property right in the leased goods to use and control them, to extract as much value out of them as possible. However, the employer cannot squeeze anything out of the employee-it cannot put in motion the capacity to produce value that it has leased-without the latter's simultaneous engagement of her will. The use and control of this value-producing asset requires that the employee continuously renew her contractual assent. The father of institutional economics, John Commons remarked, "His [the worker's] bargaining is his act of producing something for the employer and his producing something acceptable is his method of bargaining." The "laborer is thus continuously on the labor market - even while he is working at his job he is both producing and bargaining, and the two are inseparable." 50

The problem is, we cannot distinguish the employment relationship from the independent contracting relationship unless we can distinguish when the parties are bargaining from when they are producing. The means-ends standard depends on the ability to recognize when the parties are on the "market" and when they are in the abode of production: The right to contract over the terms and

${ }^{48}$ The $13^{\text {th }}$ Amendment prohibition on involuntary servitude is likely an obstacle to exchanging labor effort as a contractual commodity. In the 19th century, judges began to find that indentured servitude could be "involuntary," even if the servant initially agreed to the arrangement voluntarily. STEINFELD, supra note _, at 144-145.

${ }^{49}$ If we could alienate the capacity to will, we would not have the capacity to contract.

${ }^{50}$ Commons, supra note _, at 285. 
conditions of the labor services is a feature of both employment and independent contracting. What distinguishes employment is whether there is control over production. The employer controls the "means and manner" of the work, not just the "ends" of the work, over which all parties have a right to drive hard bargains. Since contracting and producing are simultaneous in employment, however, employer and employee never conclude a contractual negotiation and proceed to a discrete activity of producing. In employment, contractual formation regarding the "ends" of the work is simultaneous to producing - the "means" of the work or contractual performance. Independence in contracting is simultaneously subordination in production.

\section{The Problem of Indefiniteness}

Regardless of whether the employment is at-will, the promise as consideration option is generally unavailable in employment, because it would tend to create contracts too indefinite to enforce. Further, to save some contracts from indefiniteness and to police the conduct of the parties, courts will imply contractual terms or use other gap-fillers. They do not do so when interpreting employment agreements.

Again, by definition, the employee agrees to obey the employer's instructions; however, these instructions will often determine essential parts of the bargain. ${ }^{51}$ In particular, employment lacks a quantity term - the employee agrees to place his or her energies under the employer's right of control, and the employer promises a certain payment. $^{52}$ The exchange is for an indefinite amount of labor for a definite amount of payment. How much labor the employee provides is determined in the course of production. The employer seeks to convert the employee's capacities into as much

${ }^{51}$ Promises to obey one party's reasonable instructions when these promises would not give one party the right to determine something as important as the quantity term tend to be acceptable. For instance, a bailor may agree to follow the bailee's reasonable instructions about how to handle its property, or a seller might promise to follow a buyer's reasonable directions regarding delivery.

52 See, e.g., U.C.C. $\S 2-201$ cmt. 1 (2012) (requiring quantity term in contracts); see also id. § 2-306 cmts. 1-3 (requiring good faith when conforming to quantity estimates); Ian Ayres \& Robert Gertner, Filling Gaps in Incomplete Contracts: An Economic Theory of Default Rules, 99 YALE L.J. 87, 95 (1989) (discussing UCC default rules for filling in price and quantity terms). 
completed work as possible; the employee seeks to regulate this intensity. Critical terms of the conversion tend to go specified: How hard should the employee work? How fast? With what rights to object? ${ }^{53}$ Employment resembles the unenforceable "agreement to agree." 54

Employees and employers can bargain about many features of the relationship, and they may seek to limit the employer's otherwise nearly unlimited right to dispose of the employee's capacities. With limited exceptions, provided mainly by statute, the terms are unenforceable. Rather than rights to damages or equitable relief, the parties have the right to exit the relationship.

While all contracts are incomplete, employment is incomplete by design. Outside bodies, like courts or arbitrators, have authority to interpret non-employment contracts. Contract law has a repertoire of interpretive principles and standardized terms to fill contractual gaps and ambiguities. ${ }^{55}$ Their content may be based on, for example, industry standards, a course of dealing or performance between the parties, or relevant statute. Further, the courts imply a covenant of good faith in other contracts. In a non-employment contract, the parties may agree that one party will have discretion to interpret contractual terms and fill certain gaps; however, courts or arbitrators determine whether the interpretation is consistent with the parties' intent and not an abuse of discretion. ${ }^{56}$

By contrast, when courts and treatise writers incorporated master-servant status into contracts for labor services, they gave the employer an implied authority to determine unspecified or ambiguous elements of the agreement. ${ }^{57}$ Employers are generally not

53 Selznick 134-35; Alan Fox, Beyond Contract 183-84 (1974); James B. AtLeson, VAlues and Assumptions in AMERICAN LABOR LAW 11-15 (1983). See also U.C.C. § 2-201 cmt. 1, § 2-306 cmts. 1-3 (2013); Ian Ayres \& Robert Gertner, supra note $-$

${ }^{54}$ C.f. Sun Printing \& Publ'g Ass’n v. Remington Paper \& Power Co., 139 N.E. 470, 471 (N.Y. 1923) (“agreement to agree” unenforceable).

${ }^{55}$ In commercial requirements and outputs contracts, for example, which also lack a specified quantity for exchange, courts require exclusive dealings to support a contract, will impute "reasonable" maximum and minimum quantities, and impose a duty of good faith. E.g., Mid-South Packers, Inc. v. Shoney’s, Inc., 761 F.2d 1117 (5th Cir. 1985); U.C.C. § 2-306 cmts. 1-3, 5 (2013).

${ }^{56}$ See, e.g., Centronics Corp. v. Genicom Corp., 562 A.2d 187 (N.H. 1989).

57 Christopher L. Tomlins, Law and Power in the Employment Relationship, in LABOR LAW IN AMERICA: HistORICAL AND CRITICAL EsSAYs 71-98, 74 (Christopher L. Tomlins \& Andrew J. King eds., 1992). 
subject to the scrutiny of contract law as to whether the employer's interpretation of the agreement comports with the parties' intent, or whether the employer is performing the agreement in good faith. For instance, the court will not imply a term that would limit an employee's duty to obey the employer to the latter's "reasonable" commands. This implied right includes circumstances where the employer seems unilaterally to change agreed-upon terms. ${ }^{58}$ The basic remedy is exit. The essence of the employment contract is extra-contractual discretion. ${ }^{59}$

\section{Employment and Power}

What does it mean then to say the employer has a "right" to control the work of an employee? It means, simply, that we can recognize something as an employment relationship when one party to a agreement for labor services has such greater bargaining power that it can impose its will on the other: The right to control the work means the employer will likely get its way in the course of the parties' negotiations. The legal definition of the employment contract registers the inequality of bargaining power between employer and employee.

\section{Interpretative Ambiguities}

The tension between master-servant authority and contract limned above creates two interpretative ambiguities in disputes over employment status. The first, explained above, is to make ambiguous the activities of bargaining over the work and carrying out the work.

The second ambiguity, surfaces in attempts to interpret a written work agreement, rather than in distinguishing the activities of

${ }^{58}$ Fox, supra note _, at 183-84; see also AtLeson, supra note _, at 13; SELZNICK, supra note _, at 132, 136; Ayres \& Gertner, supra note _. The ability to quit does not afford both parties equal rights to interpret the contract. When an employer pays less than agreed upon, the employee generally must look for relief to an statute requiring payment of promised wages. Likewise, employees seeking promised bonuses, commissions, holidays, other benefits, or damages from broken promises regarding the former must generally look for a relevant state statute.

59 Christopher L. Tomlins, Law and Power in the Employment Relationship, in LABOR LAW IN AMERICA: HistORICAL AND CRITICAL EsSAYs 71-98, 74 (Christopher L. Tomlins \& Andrew J. King eds., 1992). 
bargaining and producing. The means-ends standard depicts employment as a contract, but a peculiar kind of contract. In ordinary contracts, parties commit one another to the "ends" of the deal, but neither has a right to dictate how the other party satisfies these ends. The employment contract, however, gives one party an implied right to determine how the other party satisfies its contractual duties: the employer has a right to control not only the "ends" of the work, but also the "means" of the work. The means-ends standard therefore depends on being able to distinguish between contractual duties and the manner of their performance, in order to evaluate whether one party is controlling the latter but not the former. The problem, again, is that the fusion of master-servant authority with contract makes illusory any distinction between contractual duties and how they are performed. Employer and employee exchange performance for performance and determine their contractual duties as they produce. In employment, we cannot identify the contractual duties.

Part V illustrates how this ambiguity turns the interpretation of a written work agreement into a puzzle in disputes over employment status. The IC decisions take the position that everything stated in the written document the drivers signed states a contractual end, which, by definition prohibits FedEx from controlling how drivers perform these ends. Other courts recognized that the contract by its terms gave FedEx a right to control the contractedfor ends or collapsed the distinction altogether, revealing an employment relationship.

In sum, the attempt to fit employment in the framework of contract creates an ambiguity between the activities of bargaining and producing, and an ambiguity between contractual duties and how they are performed. Both make the dominant standard for distinguishing employment from independent contracting relationships-the means-end standard-irresolvable. Applying the means-end standard requires distinguishing the activities of bargaining and producing, and, when interpreting a written agreement, distinguishing between contractual duties and the way in which they are performed. 


\section{E. Employment as Institution}

Marx referred to the market, "within whose boundaries the sale and purchase of labour power goes on," as a "very Eden of the innate rights of man," where "alone rule Freedom, Equality, Property, and Bentham." Employer and employee then "desert[]" this "noisy sphere, where everything takes place on the surface and in view of all men" and enter the "hidden abode of production."60

However, since employer and employee negotiate and produce at the same time, since the means-ends standard cannot distinguish between contractual duties and their performance, how do judges distinguish the "noisy sphere" from the "hidden abode of production?" How do they distinguish where parties meet as equals-in contract-from where they meet as superior and subordinate-in production? The apparent coordinates of contracting and production in time and space are artifacts of practice. The intelligibility of employment is dependent on its institutionalization.

In an industrial manufacturing firm, human resources personnel might hire the worker and explain salary and benefits. Later, distinct personnel in a manufacturing division might supervise the worker on the factory floor. These organizational markers of industrial employment separated the productive process from the sorting of workers in the labor market and the contracting process. Judges interpreting nonstandard work must find a way to makes sense of the disorganized temporal, spatial, and bureaucratic markers of industrial employment.

NLRB v. Labor Ready ${ }^{61}$ illustrates the task. This NLRA case concerned a non-solicitation policy that a temporary employment agency's imposed in its waiting area. The legality of the policy depended on whether persons registered with the agency were employees of the agency while they were waiting for assignments. The company argued that, although it was mandatory for registrants to be in the waiting room in order to receive job placements, their employment relationship with the agency ended between each assignment or after each day of work. The court rejected this argument. It argued that requiring registrants' physical presence at

${ }^{60}$ Karl MarX, Capital, in Karl Marx: Selected Writings 452, 492 (2d ed., David McClellan ed., Oxford Univ. Press 2005) (1867).

${ }^{61}$ NLRB v. Labor Ready, Inc., 253 F.3d 195 (4th Cir. 2001). 
the agency to receive assignments was a form of control over their work; the employment relationship continued between assignments.

The work arrangement in Labor Ready lacked the temporal, spatial, and bureaucratic markers of the prototypical industrial firm that separated the hiring process from supervisory direction. The company interpreted registrants looking for jobs in the waiting room as an aspect of labor market sorting, or contracting. The court, in contrast, interpreted the waiting room requirement as an part of the company's process of producing its saleable service, which was to make workers available on-demand to client firms.

The FedEx disputes, and the IC decisions in particular, suggest that the law's attempt to construe employment as a contract renders even those work relations approaching the prototype of industrial employment susceptible to redefinition.

\section{FROM BARGAINING TO PRODUCING}

The way that FedEx organized the drivers' work manipulated the ambiguities in the employment contract between bargaining and producing. This enabled the courts to find that features of the work that under the legal tests would be probative of an employment relationship were here consistent with, or even evidence of, an independent contracting relationship. The IC decisions marshaled the ambiguity between producing and contracting to negate or invert the legal meaning of nearly every factor under the legal tests indicative of employment and to transform several features typical of industrial work into evidence of entrepreneurial opportunity: delivery route assignments, supervision, discipline, promotions, shift replacements, training, skill, tenure, at-will authority, scheduling, and other work rules.

\section{A. Route Assignments, Training, and Execution of the Contract as Institutional Marker}

\section{Control or Entrepreneurial Opportunity?}

In what we think of as the formation of a "typical" employment arrangement, a worker applies for a job. If accepted, the worker meets with Human Resources personnel, perhaps signs an agree- 
ment, and then receives a desk, a phone-whatever the required equipment for the job. And, often the worker receives training from the company or participates in orientation.

For FedEx drivers, the sequence differs. A potential driver completes a computerized application and undergoes a physical examination and drug screening. ${ }^{62}$ Next, those approved by FedEx who do not have satisfactory commercial driving experience must take a training course. ${ }^{63}$ Some approved drivers also received training from FedEx and began working as FedEx drivers through a temporary agency. ${ }^{64}$ To become permanent, the applicant must buy or lease a truck. Until 2008, FedEx furnished or financed trucks for sale or lease to drivers. ${ }^{65}$ The truck must fit FedEx's detailed specifications (down to the brand and shade of white paint) for FedEx trucks generally and must be approved for a particular delivery route. ${ }^{66}$ Only after all this would a FedEx terminal manager present the driver with a written agreement. Only in signing the agreement does the driver officially receive the delivery route and become a FedEx driver. ${ }^{67}$

Ordinarily, assigning a worker to a particular service area or a driver to a particular delivery route, ${ }^{68}$ and training a worker, ${ }^{69}$ are

62 FHD NLRB Reg. Dir. decision 2006 at 10-12; Fedex Home Delivery, 361 N.L.R.B. No. 55, 2014 WL 4926198, at *4 (Sept. 30, 2014).

${ }^{63}$ Kansas decision, 734 F.Supp.2d at 562-63; FHD NLRB Reg. Dir. decision 2006 at $11-12$;

${ }^{64}$ FHD NLRB Reg. Dir. decision 2006 at 10; FedEx Ground Package Sys., Case 22RC-12508, slip op. at 26 (Nov. 2, 2004); Fedex Home Delivery, 361 N.L.R.B. No. 55, 2014 WL 4926198 at *4 (Sept. 30, 2014). Drivers performed the same work whether hired as contractors or temporary employees. FHD NLRB Reg. Dir. decision 2006 at 11; Fedex Home Delivery, 361 N.L.R.B. No. 55, 2014 WL 4926198, at *4 (Sept. 30, 2014).

${ }^{65}$ Up until 2008, FedEx purchased custom-made trucks and sold or leased them to potential drivers. FedEx continued to maintain relationships with outside vendors willing to finance FedEx drivers. Kansas decision, 734 F.Supp.2d at 566; Estrada, 154 Cal.App.4th at 12 .

${ }^{66}$ FHD NLRB Reg. Dir. decision 2006 at 11-12, 13, 17-18; FHD, 563 F.3d at 501; Kansas decision, 734 F.Supp.2d at 565-66, 592; Alexander v. FedEx Ground Package Sys., 765 F.3d 981, 986, 989 (9th Cir. 2014); Slayman v. FedEx Ground Package Sys., 765 F.3d 1033, 3 (9th Cir. 2014).

67 FHD NLRB Reg. Dir. decision 2006 at 13-14; Fedex Home Delivery, 361 N.L.R.B. No. 55, 2014 WL 4926198, at *4 (Sept. 30, 2014). See also Deposition of Penny Massa at 4-6, Multi-state decision, 758 F.Supp.2d 638, 2005 WL 5865334 (No. 3-05MD-527-RM).

68 See, e.g., Solis v. Velocity Exp., Inc., No. CV 09-864-MO, 2010 WL 3259917, at *7 (D. Or. Aug. 12, 2010). 
evidence of employer control over production-evidence of employment.

FedEx, however, suggested that drivers' meetings with terminal managers were part of the bargaining process. ${ }^{70}$ Thus, the work relationship did not really begin until after the drivers signed the contract. For instance, according to the former CEO of FedEx, when a driver checked with a manager to see if a certain truck would be permissible for the route to be assigned, it presented FedEx with a "business plan." 71 FedEx manipulated the ambiguity within the employment contract by relocating the conventional threshold between bargaining and production in industrial, or typical,” employment (Figure 1). Everything that fell on the precontract signing side of the relationship appears as part of the market sorting or bargaining process.

\section{Figure 1}
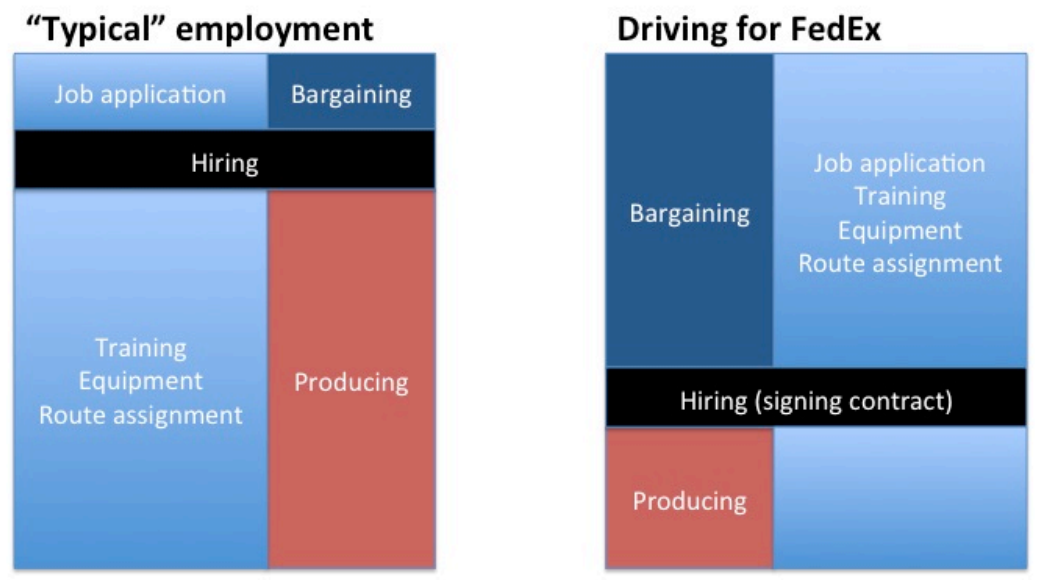

In reality, drivers had little leeway to make rational investment decisions based on their "proprietary interest." FedEx maintained

${ }^{69}$ See, e.g., Crawford v. State, 845 P.2d 703, 706-07 (Kan. Ct. App. 1989); NLRB. v. United Ins. Co. of Am., 390 U.S. 254, 259 (1968).

${ }^{70}$ Brief of Petitioner/Cross-Respondent at 6-7, 52-53, FHD, 563 F.3d 492, 2008 WL 4425826 (Nos. 07-1391, 07-1436).

${ }^{71}$ Kansas decision, 734 F.Supp.2d at 565-566. 
strict control over the volume of package deliveries in each service area. Using advanced logistics technology and supervisory ridealongs, it structured drivers' routes so that each driver would have 9-11 hours of deliveries per day. ${ }^{72}$ Regardless of the desirability of a driver's initial route assignment, FedEx had the right to alter the routes unilaterally and regularly did so to distribute work somewhat evenly among drivers. ${ }^{73}$ (The document the drivers signed expressly stated that a driver's "proprietary" interest was limited to their service area "as that area is configured from time to time" unilaterally by FedEx. ${ }^{74}$ ) Drivers were required to deliver every package FedEx assigned to them each day. Further, although a property right usually includes the right to exclude, FedEx adjusted packages among drivers daily. Drivers were required to deliver packages outside of delivery areas and to allow other drivers to make deliveries in their own service areas. ${ }^{75}$ And, if delivery volume increased on a particular route, under the driver's compensation formula, FedEx offset the increase in piece rate earnings for packages by decreasing the driver's daily wage, which was inversely correlated to delivery volume and geographic density. ${ }^{76}$ FedEx largely predetermined drivers' pay based on hours of work. ${ }^{77}$ By design, bargaining over delivery areas was not a meaningful source of entrepreneurial opportunity for most drivers.

${ }^{72}$ Kansas decision, 734 F.Supp.2d at 570, 589, 590, 591. See generally Richard Mason, James L. McKenney, Walter Carlson, and Duncan Copeland, Absolutely, Positively Operations Research: The Federal Express Story, 27 InTERFACES 17 (1997). See also FedEx Ground Package Sys., Case 22-RC-12508, slip op. at 75 (Nov. 2, 2004) (FedEx supervisor took into account how much break-time driver took in determining route structure).

${ }^{73}$ Kansas decision, 734 F.Supp.2d at 573-574; FedEx Ground Package Sys., Case 22-RC-12508, slip op. at 54 (Nov. 2, 2004).

${ }^{74}$ See Pick-up and Delivery Contractor Operating Agreement at 9 5.2, Exhibit, Defendant's Memorandum of Law and Supplemental Statement in Opposition to Leighter (Oregon) Motion for Class Certification, Leighter v. FedEx Ground Package Sys., Inc., 2007 WL 6930366 (N.D.Ind. 2007) [hereinafter Operating Agreement].

75 Kansas decision, 734 F.Supp.2d at 561, 569-70; Brief of Petitioner/CrossRespondent at 6-7, FHD, 563 F.3d 492, 2008 WL 4425826 (Nos. 07-1391, 07-1436); Operating Agreement at 9 5.1.

${ }^{76}$ Kansas decision, 734 F.Supp.2d at 567, 589; Alexander v. FedEx Ground Package Sys., 765 F.3d 981, 985 (9th Cir. 2014).

${ }^{77}$ See, e.g., Kansas decision, 734 F.Supp.2d at 567 (daily wage rate calculated based on hours of assigned work); Deposition of Michael Callahan, Kansas decision, 734 
However, the courts finding the drivers to be independent contractors largely followed FedEx's cues with respect to the company's manipulation of the institutional markers of industrial employment. They did not find the route assignments to be evidence of FedEx's right to control the means of the work. ${ }^{78}$ The D.C. Circuit suggested that route assignments were evidence of entrepreneurial opportunity, because a driver might acquire a delivery route with expanding package volume. ${ }^{79}$ Judge Miller suggested they went to FedEx's control only over "results" of the work; he characterized them not as an assignment of work by FedEx, but as a driver's contractual agreement to service a particular area. ${ }^{80}$ Both courts emphasized drivers' contracted-for "proprietary" rights as key to their finding that drivers were independent contractors, on the basis that it revealed their entrepreneurial opportunity. ${ }^{81}$ The IC decisions thus reinterpreted delivery area assignments as evidence of independence in bargaining rather than dependence in producing.

The courts also reinterpreted or lessened the import of the drivers' training and FedEx's control over the delivery vehicles. Judge Miller asserted that the training drivers underwent before signing the contract "isn't training, but a precondition, to becoming a contractor." 82 The D.C. Circuit suggested that the training requirement was insubstantial evidence of employment status in the FedEx situation, merely reflecting the results the drivers contracted to provide, or the "type of service the contractors are providing rather

F.Supp.2d 557, 2005 WL 5865335 (No. 3:05-MD-527-RM); FedEx Ground Package

Sys., Case 22-RC-12508, slip op. at 44-45 (Nov. 2, 2004).

${ }^{78}$ FHD, 563 F.3d 492; Kansas decision, 734 F.Supp.2d 557.

${ }^{79}$ FHD, 563 F.3d at 500 (arguing "routes are geographically defined, and they likely have value dependent on those geographic specifics which some contractors can better exploit than others. For example, as people move into an area, the ability to profit from that migration varies”).

${ }^{80}$ Kansas decision, 734 F.Supp.2d at 589 ("Various provisions of the Operating Agreement authorize FedEx to control the days of service, the contractor's daily workload, and certain time windows when pick-ups and deliveries must be made. These requirements weigh in favor of employee status, but are more suggestive of a resultsoriented approach to management when viewed with the totality of circumstances.”)

${ }^{81}$ FHD, 563 F.3d at 502, 503; Kansas decision, 734 F.Supp.2d at 596-97, 601.

${ }^{82}$ Kansas decision, 734 F.Supp.2d at 563. Based in part on the additional training FedEx provided after drivers signed the agreement, Judge Miller found that the training factor weighed somewhat in favor of employee status. Id. at 595. 
than differences in the employment relationship." 83 Agreeing with FedEx, ${ }^{84}$ the D.C. Circuit suggested that drivers "invested" in an independent business by purchasing or leasing FedEx trucks. ${ }^{85}$

FedEx's manipulation of the bargaining/producing ambiguity formed a basis for disagreement among the courts. Several other courts found the route assignments to be evidence that the drivers were employees. ${ }^{86}$ For example, in two decisions, the 9th Circuit argued that the route assignments were evidence of FedEx's control over the means of the work, not merely the results. ${ }^{87}$ The Kansas Supreme Court remarked, "the procedure by which a driver becomes qualified to deliver packages for FedEx more closely resembles the process by which employees are hired than the process by which independent contractor agreements are negotiated. ${ }^{88}$

The extent that drivers "invested" in their own businesses was also a point of disagreement. The NLRB and a federal district court suggested the FedEx-specific nature of the vehicles and their use of the trucks for a regular and integral service of the alleged employer's business augured an employment relationship. ${ }^{89}$ The Kansas Supreme Court argued that requiring drivers to purchase some of the tools of work did not so much show that drivers invested in

\footnotetext{
${ }^{83}$ FHD, 563 F.3d at 501.

${ }^{84}$ Reply Brief of Petitioner/Cross-Respondent at 24, FHD, 563 F.3d 492, 2008 WL 4425828 (Nos. 07-1391, 07-1436).

85 The D.C. Circuit characterized the requirement that drivers purchase or lease FedEx trucks as drivers "suppl[ying] their own equipment" and argued that this indicated entrepreneurial opportunity. FHD, 563 F.3d at 498, 503. The $9^{\text {th }}$ Circuit, though it ultimately found the drivers to be employees as a matter of law, also found the tools factor, when considered alone, to weigh slightly in favor of independent contractor status. Alexander v. FedEx Ground Package Sys., 765 F.3d 981 (9th Cir. 2014); Slayman v. FedEx Ground Package Sys., 765 F.3d 1033, 10 (9th Cir. 2014).

${ }^{86}$ Craig v. FedEx Ground Package Sys., Inc., 335 P.3d 66, 82-83 (Kan. 2014); Wells v. FedEx Ground Package Sys., 979 F.Supp.2d 1006, 1019 (E.D. Mo. 2013) (noting that service areas were "assigned" by FedEx and suggesting that true independent contractors found their own work).

87 Alexander v. FedEx Ground Package Sys., 765 F.3d 981, 990 (9th Cir. 2014); Slayman v. FedEx Ground Package Sys., 765 F.3d 1033, 1044 (9th Cir. 2014).

${ }^{88}$ Craig v. FedEx Ground Package Sys., Inc., 335 P.3d 66, at *807 (Kan. 2014).

${ }^{89}$ Fedex Home Delivery, 361 N.L.R.B. No. 55, 2014 WL 4926198, at *19 (Sept. 30, 2014) (noting that investment in FedEx trucks and equipment suggests long-term relationship). Wells v. FedEx Ground Package Sys., 979 F.Supp.2d 1006, at *6, 13 (E.D. Mo. 2013).
} 
their own businesses, but rather that they invested in their FedEx jobs. $^{90}$

\section{Contract Execution as Temporal, Institutional Marker}

Since the legal standard cannot distinguish where employer and employee meet as equals - in contract-from where they meet as superior and subordinate-we create institutional markers to do so. Like a Human Resources department or other bureaucratic marker, the written contract appears as an institutional index tab: It purports to divide the work relationship into distinct and legally cognizable segments - the ends of the work and the means of the work, or contractual negotiation and performance.

FedEx and the IC decisions construct the contract signing as an institutional marker of non-employment: everything that happens before the contract signing is bargaining over the work; only what happens afterwards is production. A driver's execution of a written agreement signals the relationship is one of independent contracting by marking a clear break between the negotiation process and the endowment of enforceable rights. ${ }^{91}$

\section{A Critique}

Despite the inherent ambiguity within the employment contract between bargaining and producing, the construction of the execution of the written agreement as an institutional marker of nonemployment is problematic for both doctrinal and policy reasons. The written document the drivers sign is not performing the work of a contract: it is not separating the market sorting and bargaining process from the carrying out of an enforceable contract.

${ }^{90}$ Craig v. FedEx Ground Package Sys., Inc., 335 P.3d 66, at *822-23 (Kan. 2014). Given that in several cases drivers suing under statutes that prohibited employers from charging employees for business expenses, it seems rather circular to argue that requiring drivers to buy or lease their work trucks was evidence of the law's inapplicability, rather than evidence of FedEx's violation of the law (in spirit).

${ }^{91}$ For another example, see Solis v. Velocity Express, No. CV 09-864-MO, 2010 WL 3259917 at *5 (D. Or. Aug. 12, 2010), an overtime case involving a shipping company that converted its delivery drivers from employees to independent contractors. The court queried whether the company's route assignments were evidence of the company's "control over its workers or simply an unprofitable contractual bargain." It found that the "critical evidence" was that drivers "received their route assignments after they contracted with Velocity Express.” Id. at *6 (emphasis added). 
As a doctrinal matter, drivers begin submitting to FedEx's authority as employees before they sign the agreement. They receive training and begin following FedEx's directions in acquiring and outfitting a truck for an assigned route. The relationship is closer to that of a master-servant relationship than a contract. Secondly, as noted above, post-signing the agreement did not provide the drivers with meaningful business property in their routes that they could exploit as entrepreneurs.

As a policy matter, recall that the drivers in the IC decisions were trying to unionize and exercise rights to statutory wages. At a minimum, these laws are intended to protect vulnerable workers. FedEx and the IC decisions' resolution of the ambiguity between bargaining and producing disrupts these policy objectives. FedEx hired drivers without any requirements as to skill, experience, or capital. ${ }^{92}$ The unskilled nature of the work was evidence that the drivers should be classified as employees under the legal tests. ${ }^{93}$ FedEx also dictated all of the instrumentalities of work and restricted drivers' property rights in the vehicles. ${ }^{94}$ These characteristics of the relationship also suggested it fit well within the policy scope of collective bargaining and minimum wage and hour law. Shifting the temporal site of contract signing does not correspond to a transmutation of bargaining power.

By manipulating the sequencing of the contract signing, however, rather than bargaining with an unskilled and property-less

92 See, e.g., Kansas decision, 734 F.Supp.2d at 562, 599 (describing “minimal eligibility requirements" to become a FedEx driver and ability to learn the required skills through FedEx's training or supervision on the job); FHD NLRB Reg. Dir. decision 2006 at 10-11 (describing process of becoming a FedEx driver).

93 See, e.g., Kansas decision, 734 F.Supp.2d at 599; FHD, 563 F.3d at 507 (citing RESTATEMENT (SECOND) OF AGENCY § 220(2) (1958).

94 See, e.g., Craig v. FedEx Ground Package Sys., Inc., 335 P.3d 66, at *808 (Kan. 2014); Kansas decision, 734 F.Supp.2d at 597; FHD, 563 F.3d at 514 (dissent); Wells v. FedEx Ground Package Sys., 979 F.Supp.2d 1006, at *13 (E.D. Mo. 2013). Drivers' most valuable property rights in their vehicle ownership or leases appeared to be the ability to sell them, particularly to other FedEx drivers. Rather than give drivers' autonomy over their market destinies, requiring drivers to purchase the vehicles tended to limit their ability to quit. It saddled drivers with debt payments for a truck that had little commercial use apart from servicing FedEx. See Greenhouse, supra note _; Deposition of Michael Callahan, Kansas decision, 734 F.Supp.2d 557, 2005 WL 5865335 (No. 3:05-MD-527RM). Furthermore, FedEx limited drivers' use of their vehicles for non-FedEx purposes. Kansas decision, 734 F.Supp.2d 557. FedEx could also suspend a driver without notice, lock the driver's truck in the terminal, and prevent the driver from accessing it. (N.D. Ind.) 
worker, it appears that the company is bargaining with an independent business - one that happens to possess the requisite equipment, skill, and knowledge. The D.C. Circuit, for example, did not address the skill factor at all, and it commented, "Servicing a route is not cheap; one needs a truck (which the contractor pays for) and a driver (which the contractor also pays for, either directly or in kind)." 95 Rather than meeting as subordinate and superior on the factory floor, drivers seem to meet FedEx as equals at the bargaining table. ${ }^{96}$

\section{B. Negotiation or Unilateral Changes to Work Duties?}

The IC decisions also reinterpreted FedEx's right to alter routes unilaterally as evidence consistent with independent entrepreneurialism. FedEx regularly monitored delivery volumes on each route and reconfigured routes to even out workloads among drivers as deliveries expanded or contracted. This reflects the continuing and simultaneous bargaining and directing of the work that characterizes an employment relationship, where FedEx, as the stronger party, always prevails. The IC decisions exploited the ambiguity between contracting and producing to interpret FedEx's adjustments to drivers' delivery routes as frequent re-openings of the negotiation process.

The D.C. Circuit, for example, accepted FedEx's characterization of the company's right to unilaterally alter routes (in return for some compensation) as a "Mutual Intention to Reduce the Geographic Size of Primary Service Area." 97 To keep its route in the case of expanding business, FedEx might require a driver to acquire additional trucks and supervise other FedEx drivers. If a driver found this infeasible or undesirable, FedEx could change the driver's route. FedEx characterized a driver's submission to a mandatory route change as a driver "decid[ing] to forgo the busi-

\footnotetext{
${ }^{95}$ FHD, 563 F.3d at 500.

${ }^{96}$ The courts' emphasis on entrepreneurial opportunity also tended to suppress the legal weight of the unskilled nature of the work. FedEx and Judge Miller suggested that entrepreneurialism was a skill. Kansas decision, 734 F.Supp.2d 557 (suggesting that the agreement required drivers to have business management skills).

${ }^{97}$ FHD, 563 F.3d 492; Reply Brief of Petitioner/Cross-Respondent at 20, 22, FHD, 563 F.3d 492, 2008 WL 4425828 (Nos. 07-1391, 07-1436). 20, 22 (quoting Operating Agreement drivers signed).
} 
ness growth opportunity" ${ }^{98}$ Note the language of equality in bargaining rather than subordination in production. While it might appear that FedEx was controlling the work in determining delivery areas, the parties were really just reopening negotiations. If FedEx always managed to prevail, it was by driving a hard bargain, not being an employer.

Once a court concludes that most features of the relationship that might suggest subordination or inequality were incidents of bargaining rather than production, they became irrelevant to the court's decision, and even taboo, as an issue of bargaining power. The D.C. Circuit thus remarked, "we will 'draw no inference of employment status from merely the economic controls which many corporations are able to exercise over independent contractors with whom they contract." 99

A California Appellate Court rejected FedEx's characterization of route assignments as evidence of independence in bargaining, noting that the terminal managers who assigned routes were "drivers' immediate supervisors and can unilaterally reconfigure the drivers' routes without regard to the drivers' resulting loss of income." 100

\section{Termination or Aborted Negotiation?}

The authority to terminate a worker at-will is generally evidence of employment rather than independent contracting under the legal standards for employment status. ${ }^{101}$ By default, employment in the U.S. is an at-will relationship, meaning either party may terminate it at any time for a good reason, a bad reason, or no

${ }^{98}$ Reply Brief of Petitioner/Cross-Respondent at 22, FHD, 563 F.3d 492, 2008 WL 4425828 (Nos. 07-1391, 07-1436).

${ }^{99}$ FHD, 563 F.3d at 502, n. 8 (citing NAVL, 869 F.2d at 599). See also, Fedex Home Delivery, 361 N.L.R.B. No. 55, 2014 WL 4926198, at *26 (Sept. 30, 2014) (Johnson dissenting) (characterizing FedEx's control over routes and its right to disapprove of an assignee to a driver's job as a use of "contractual power" and arguing that contractual power is a prohibited consideration under the governing test for employment status).

100 Estrada v. FedEx Ground Package Sys., 64 Cal. Rptr. 3d 327, 336 (Ct. App. 2007). At some point, FedEx modified the document signed by the Estrada drivers. The new document reserved FedEx's right to unilaterally change the routes but provided a formula to compensate drivers who lost pay due to a reconfiguration. Kansas decision, 734 F.Supp.2d at 574; FHD, 563 F.3d at 501.

${ }^{101}$ See e.g., Kansas decision, 734 F.Supp.2d at 598; Borello, 769 P.2d at 404. 
reason at all. ${ }^{102}$ Performing continuous services for a long, indefinite period of time is also evidence of employment. ${ }^{103}$ Usually, independent contractors are hired to "achieve a specific result that is attainable within a finite period of time." 104

The FedEx drivers signed an initial contract of one, two, or three years that renewed automatically. FedEx had a right to cancel the renewal without cause. ${ }^{105}$ The company claimed that its fixedterm contracts drivers were evidence that the drivers were independent contractors. ${ }^{106}$ In practice, FedEx hired drivers for long periods of time ${ }^{107}$ and their work-delivering packages to FedEx customers - continued indefinitely. FedEx also awarded vacation time based on driver seniority. ${ }^{108}$

Recall that, in contractual terms, the employer and employee bargain over their relationship and perform it at the same time. To the extent employment is a contract, it is continuously renewed at each moment the relationship endures. ${ }^{109}$ To say that employment is "at-will" simply means that at some moment the employer and/or employee decide not to renew the contract. Maybe the employee decides not to accept the employer's terms and conditions conveyed through the employer's direction of the work. Or, perhaps the employer feels the employee has not agreed to its terms by performing deficient work. Regardless of the reason, the parties stop bargaining.

The ambiguity between the activities of contracting and producing enabled the courts ruling for FedEx to interpret FedEx's partial at-will authority as evidence of independent contracting. Judge Miller suggested that, rather than evincing a right to terminate a driver, this simply showed that FedEx had a right not to en-

102 See, e.g., Lake Land Emp. Grp. of Akron, LLC v. Columber, 2004-Ohio-786, ๆ 17, 101 Ohio St. 3d 242, 247, 804 N.E.2d 27, 32.

103 See, e.g., Nationwide Mut. Ins. Co. v. Darden, 503 U.S. 318, 323 (1992) (citing Community for Creative Non-Violence v. Reid, 490 U.S. 730, 751-52 (1989).

104 Antelope Valley Press v. Poizner, 75 Cal.Rptr.3d 887, 900 (2008).

105 Kansas decision, 734 F.Supp.2d at 574, 596; FHD NLRB Reg. Dir. decision 2006 at 16.

${ }^{106}$ Craig v. FedEx Ground Package Sys., Inc., 335 P.3d 66, *817 (Kan. 2014); FedEx Summary Judgment Brief at 15, Craig, 335 P.3d 66.

${ }^{107}$ In a California case, the average driver worked for FedEx for 8 years. Estrada v. FedEx Ground Package Sys., 64 Cal. Rptr. 3d 327, 337 (Ct. App. 2007).

${ }^{108}$ FHD NLRB Reg. Dir. decision 2006 at 25-26.

${ }^{109}$ See supra Part II. 
gage in "repeat business." $110 \mathrm{He}$ argued that the right to cancel a driver's contract renewal without cause “isn't atypical of an independent contractor relationship where a hiring party can simply decide not to re-hire a worker." 111 The court exploited the ambiguity between bargaining over the work and carrying it out to interpret FedEx's partial at-will authority as evidence of the drivers' contractual independence rather than subordination in production. ${ }^{112}$

This construction of FedEx's authority to cancel a drivers' contract renewal also dimmed the importance of the duration of the relationship and the continuous nature of the service provided. Judge characterized this practice as one bearing on contracting rather than production, noting a company "might wish to deal with reliable suppliers, middlemen, or subcontractors." 113 Noting the drivers' agreement was for a definite term, he found that the length of the relationship did not weigh in favor of either party. ${ }^{114}$

The ambiguity between bargaining and producing in employment was behind some of the disagreement among courts trying to interpret the three factors discussed above with respect to FedEx drivers - whether the relationship was at-will, the length of the work relationship, and whether the services were discrete or continuous. ${ }^{115}$ One court argued, "Plaintiffs could effectively be ter-

${ }^{110}$ Kansas decision, 734 F.Supp.2d at 595 (quoting Home Design, Inc. v. Kansas Dep’t of Human Res., 27 Kan.App.2d 242, 247(2000). See also State Comp. Ins. Fund v. Brown, 32 Cal. App. 4th 188, 203, 38 Cal. Rptr. 2d 98, 105 (1995), as modified (Feb. 8, 1995) (right to terminate contract with 14 days of notice was "consistent either with an employment-at-will relationship or parties in a continuing contractual relationship.”) C.f. Taylor v. Shippers Transp. Express, Inc., No. 2:13-cv-02092 (C.D. Cal. Sept. 30, 2014) (arguing that drayage company's right to terminate port drivers' 90-day, automatically renewable contracts on 30 days notice for any reason was equivalent to at-will authority).

${ }^{111}$ Kansas decision, 734 F.Supp.2d at 595.

112 The D.C. Circuit cited the length of service as a relevant legal factor but ignored it entirely in its analysis of the drivers' status. FHD, 563 F.3d at 496. In practice, FedEx had at-will authority over the drivers. See infra Part V.

${ }^{113}$ Kansas decision, 734 F.Supp.2d at 596. (emphasis added).

${ }^{114} \mathrm{Id}$.

115 Alexander v. FedEx Ground Package Sys., 765 F.3d 981, 996 (9th Cir. 2014) (arguing that length of time for performance of the drivers' work was evidence of employment); Fedex Home Delivery, 361 N.L.R.B. No. 55, 2014 WL 4926198, at *19 (Sept. 30, 2014) (arguing that length of relationship favored employment status, despite short-term nature of contracts); Craig v. FedEx Ground Package Sys., Inc., 335 P.3d 66, *818 (Kan. 2014) (disagreeing with FedEx that fixed term contracts were evidence that the drivers were independent contractors and arguing that the length of the relationship favored employment status); Wells v. FedEx Ground Package Sys., 979 F.Supp.2d 1006, *1-12 
minated at will given that the [agreement] provides for nonrenewal without cause."116 Another court also argued that FedEx could terminate drivers by retaining the right not to renew a driver's contract without any cause and doing so in practice. ${ }^{117}$

\section{Performance Evaluation or Bargaining?}

Interpreting FedEx's right to cancel a driver's contract renewal as a cessation of negotiations rather than as quasi-at-will authority enabled to reinterpret other factors usually indicative of employment ${ }^{118}$ as consistent with independent contracting: the right to supervise and discipline the worker.

FedEx supervised drivers and evaluated every detail of their work. Managers inspected drivers' vehicles and their personal grooming each morning and could prevent them from working or suspend them without notice if they did not pass inspection. The company monitored drivers during the day through scanning devices that recorded the location and time of each package delivery. Drivers were also subject to occasional management ride-alongs, in which a manager would sit with a drivers for the day and take detailed notes on the work, including, for example, whether a driver conveyed a “'sense of urgency,' and '[p]laces [his or her] keys on [the] pinky finger of [his or her] non-writing hand' after locking the delivery vehicle.” 119

(E.D. Mo. 2013) (duration of drivers' relationship was evidence of employee status); Estrada v. FedEx Ground Package Sys., Inc., 64 Cal. Rptr. 3d 327, *10, 11 (Ct. App. 2007). 10, 11 (citing length of relationship as evidence of employment and noting drivers had long-term relationship with FedEx). See also Estrada v. FedEx Ground, No. BC 210310, 2004 WL 5631425, at*16 (Cal. Super. Ct. July 26, 2004) (drivers have longterm relationship with FedEx).

116 Wells v. FedEx Ground Package Sys., 979 F.Supp.2d 1006, *16 (E.D. Mo. 2013).

${ }^{117}$ Estrada v. FedEx Ground Package Sys., Inc., 64 Cal. Rptr. 3d 327, *1, 10, 11 (Ct. App. 2007). Some courts found that FedEx did not have a complete right to terminate drivers without cause due to an arbitration provision in the agreement. FHD NLRB Reg. Dir. decision 2006 at 60; Slayman v. FedEx Ground Package Sys., Inc., 765 F.3d 1033, 1046 (9th Cir. 2014). At least two courts have struck down the provision.

118 See, e.g., Alexander v. FedEx Ground Package Sys., 765 F.3d 981, 994 (9th Cir. 2014) 994; FHD, 563 F.3d at 498.

119 Alexander v. FedEx Ground Package Sys., Inc., 765 F.3d 981, 990 (9th Cir. 2014). FedEx instructed managers to gather detailed information, including "the time the driver arrives and departs from each stop, the number of minutes at each stop, the number of minutes between stops, the last three digits of the driver's odometer reading at each stop, and the approximate distance the driver must walk to pick up or deliver a package.” 
Drivers were subject to regular performance evaluations, and these formed the basis for FedEx's decisions regarding bonuses, suspensions, promotions, repeated training, termination, and contract renewal. FedEx referred to the meetings as "Business Discussions," part of the contracting process, not production. FedEx also referred to the division that reviewed drivers' and made recommendations on contract termination and nonrenewal as a "Contractor Relations” division. ${ }^{120}$

The IC decisions accepted FedEx's characterization of what look to be employee performance evaluations with human resource personnel as a "Business Discussion" between an independent contractor and "Contractor Liaison." The decisions depict the performance evaluations as forward-looking bargaining between independent businesses, not control over production. For example, Judge Miller acknowledged that FedEx closely supervised the driver's work and that drivers were subject to corrective measures. However, since he decided that FedEx did not have at-will authority over the drivers, rather than control the means of the work, he argued that FedEx merely gave drivers "suggestions of best practices” for drivers to follow in producing the contracted-for-service, or "ends" of their work. ${ }^{121}$

Another court rejected FedEx's attempt to refashion some of the institutional markers of traditional employment as markers of independent contracting. It also refused to interpret FedEx's disciplinary authority as incidents of contracting:

According to [FedEx personnel], Contractor Relations is a liaison between [FedEx] and [drivers] in order to guarantee the independent contractor model. The purpose of Contractor Relations is to review recommendations for contract termination or non-renewal and to make certain that terminal managers do not overstep their bounds...However, a closer look shows that Contractor Relations is nothing more

Kansas decision, 734 F.Supp.2d at 572 (N.D. Ind. 2010). FedEx also used customer audits to review driver performance. FHD NLRB Reg. Dir. decision 2006 at 12, 21.

${ }^{120}$ FHD NLRB Reg. Dir. decision 2006 at 12, 21; Kansas decision, 734 F.Supp.2d at 594. A business discussion might involve a customer complaint, for which a manager required the driver to undergo a training course and threatened a pay penalty. In re FedEx Ground Package Sys., Inc., 273 F.R.D. 499 (N.D. Ind. 2010).

${ }^{121}$ Kansas decision, 734 F.Supp.2d at 594-595. 
than a mere branch of management...Contractor Relations must be seen in a role akin to Human Relations over employees, wherein the highest levels of management have the final say. ${ }^{122}$

This court viewed the role of Contractor Relations as consistent with an employer's open-ended authority over production, not with the discrete obligations undertaken by parties to a contract. ${ }^{123}$

\section{E. Promotion or Business Expansion?}

The interpretation of what very much resemble the internal promotion of a driver to a supervisory position offer another example of how the courts ruling in FedEx's favor drew on the tension between master-servant authority and contract to reinterpret a feature of typical employment.

A driver could ask FedEx to oversee multiple routes. FedEx had unilateral discretion over whether to grant such requests, which it exercised in part based on existing route coverage and business volume. If FedEx granted permission, the driver became responsible for "hiring" and supervising other FedEx drivers, and acquiring additional FedEx vehicles. ${ }^{124}$ FedEx limited the number of routes one driver could manage, and it retained unilateral authority to re-configure the routes and adjust packages among routes, as it did with the single route drivers. ${ }^{125}$ Any driver who worked under the supervision of a multiple route operator had to first be become a FedEx driver. They had to agree to abide by all of the rules in written agreement with FedEx. They also had to undergo the training and orientation and submit to drug testing and

122 Estrada v. FedEx Ground, No. BC 210310, 2004 WL 5631425, at *6 (Cal. Super. Ct. July 26, 2004) (emphasis added).

${ }^{123}$ The FHD dissent also suggested that "Business Discussions" resembled employee performance evaluations, noting they could lead to discipline. FHD, 563 F.3d at 513 (dissenting). While agreeing that FedEx did not have a "traditional" system of "reprimand" or "discipline," the NLRB Regional Director in FHD likewise suggested that FedEx had disciplinary authority consistent with employer status. FHD NLRB Reg. Dir. decision 2006 at 15, n.23.

${ }^{124}$ Kansas decision, 734 F.Supp.2d at 596; FHD, 563 F.3d at 499; Slayman v. FedEx Ground Package Sys., 765 F.3d 1033, *10 (9th Cir. 2014); Fedex Home Delivery, 361 N.L.R.B. No. 55, 2014 WL 4926198, *10 (Sept. 30, 2014).

${ }^{125}$ Kansas decision, 734 F.Supp.2d at 573-74, 596; FHD, 563 F.3d at 501. 
background checks. FedEx could disapprove of anyone a multiple route operator sought to hire. ${ }^{126}$ In essence, drivers could only "hire" their coworkers, with FedEx's permission.

The FHD majority and Judge Miller contended that driver requests to serve multiple routes was evidence of the entrepreneurial potential for business expansion-activity in the moment of contracting rather than evidence of internal job ladders in production. ${ }^{127}$

What looks like an internal promotion of a driver the IC decisions transformed into a driver successfully bargaining with FedEx to expand its own business. A feature of the work that ordinarily suggested employer control over productive activities-organizing a supervisory hierarchy-became an incident of bargaining over the work. ${ }^{128}$

Another court disagreed. It interpreted the company's discretionary grants of multiple routes to drivers as an activity of production-akin to an internal promotion-rather than an activity of contractual negotiation by which driver-entrepreneurs expanded their businesses:

[N]o [single-route driver] can become a[][multipleroute driver] without the consent of [FedEx] (unless without the knowledge of [FedEx], a person purchases

126 Alexander v. FedEx Ground Package Sys., 765 F.3d 981, 994 (9th Cir. 2014); Slayman v. FedEx Ground Package Sys., 765 F.3d 1033, at *10 (9th Cir. 2014); FHD NLRB Reg. Dir. decision 2006, at 40; Estrada v. FedEx Ground Package Sys., 64 Cal. Rptr. 3d 327, at *12 (Ct. App. 2007). See also Fedex Home Delivery, 361 N.L.R.B. No. 55, 2014 WL 4926198, at *10 (Sept. 30, 2014).

127 FHD, 563 F.3d at 499; Kansas decision, 734 F.Supp.2d at 596.

${ }^{128}$ FHD, 563 F.3d at 499; Kansas decision, 734 F.Supp.2d at 596. Similarly, FedEx might allow-or require-a driver to obtain an additional truck and driver. Reply Brief of Petitioner/Cross-Respondent at 21, FHD, 563 F.3d 492, 2008 WL 4425828 (Nos. 071391, 07-1436); Deposition of Michael Callahan at 6-7, Kansas decision, 734 F.Supp.2d 557, 2005 WL 5865335 (No. 3:05-MD-527-RM). Again, all extra drivers had to first form a work relationship with FedEx and be pre-approved by FedEx. See, e.g., Kansas decision, 734 F.Supp.2d at 562-63, 589. FedEx referred to a driver's acquisition of additional vehicles and its agreement to oversee other FedEx drivers as a "business growth opportunity.” Reply Brief of Petitioner/Cross-Respondent at 21, FHD, 563 F.3d 492, 2008 WL 4425828 (Nos. 07-1391, 07-1436). The IC decisions agreed with FedEx that allowing or forcing a driver to hire another FedEx driver was not evidence the FedEx controlled the means of the work, but only evidence that FedEx contracted for certain "results," and even evidence of drivers' entrepreneurial opportunity. Kansas decision, 734 F.Supp.2d at 588, 589; FHD, 563 F.3d at 504. 
another [single-route driver's] corporation that has additional routes). A new route cannot be created without the approval of [FedEx]. The chance of a [single route driver] to become a [multiple route driver] is similar to that of an associate of a law firm, who has the opportunity some day to become a partner. The mere potential of that associate to become a partner does not transform his or her employee status to that of an independent contractor. ${ }^{129}$

The courts exploit the ambiguities resulting from the awkward fit of master-servant authority and contract to negate or even invert the legal meaning of many features of the work. Many of these features indicate that the delivery drivers' relationship wit FedEx is not passable as a contractual relationship and are relevant to the policy concerns of the law.

\section{FROM HIERARCHY TO MARKET}

\section{A. Markets and Hierarchies}

Theories of the firm have attempted to explain why firms exist as an alternative to markets for organizing production, and to account for their bordering. The question is often termed, what determines whether a firm will "make" an input to production or instead "buy" an input to production? Two classic firm theorists, Ronald Coase and Oliver Williamson, defined the market in contradistinction to the firm: in markets, production was organized through decentralized, voluntary exchanges, mediated through the price mechanism. In firms, production was organized through the command relation, a "hierarchy." 130

Firms existed because market transactions were not costless. Participants to a market transaction might avoid certain costs, like

${ }^{129}$ Estrada v. FedEx Ground, No. BC 210310, 2004 WL 5631425, at *15 (Cal. Super. Ct. July 26, 2004). See also FHD NLRB Reg. Dir. decision 2006 at 3 (multiple route drivers are FedEx supervisors and their “employees" are FedEx employees).

${ }^{130}$ Ronald Coase, The Nature of the Firm 4 ECONOMICA 386 (1937); Oliver Williamson, The Vertical Integration of Production: Market Failure Considerations, 61 AmEr. ECON. ReV. 112, 114 (1971). See generally Oliver WiLliamson, MARKETS AND HIERARCHIES (1975). 
that of monitoring their transacting partners. However, they often incurred other costs. It might take time and resources to locate suitable partners, determine prices, and negotiate an agreement. ${ }^{131}$ One might be at risk to opportunistic behavior by a partner and face difficulty predicting and adapting to relevant contingencies. ${ }^{132}$ Firms would exist when the costs of organizing production through the market exceeded the costs of organizing production through fiat. ${ }^{133}$

Williamson argued that contracting costs corresponded to dimensions of the "transaction," a step in the production process. ${ }^{134}$ These dimensions were recurrence, market uncertainty, and asset specificity. Regarding recurrence, a firm might find it cheaper to make an input to production rather than repeatedly go to the market to buy it. Uncertainty about the costs of input might also motivate firm production. Asset specificity referred to the extent the parties were interdependent on one another because they incurred durable, transaction-specific investments. ${ }^{135}$

\section{B. The Firm as Employment Relationship}

Firm theories tend to associate firms and markets with different legal relations: market transactions were done through contract, while the legal authority for fiat within the firm cam from property rights and the employment relationship. ${ }^{136}$ Sometimes major theo-

\footnotetext{
${ }^{131}$ Coase, supra note _, at 386.

132 Williamson, Governance, supra note _, at 246; Williamson, Economics, supra note _, at 553; WILLIAMSON, supra note _.

${ }^{133}$ See Williamson, Economics, supra note _, at 552-553. See generally Coase, supra note _; WiLLIAMSON, MARKETS AND HIERARCHIES (1975).

${ }_{134}$ Williamson defined the "transaction" as the "transfer of a good or service over a technologically separable interface.” Economics, supra note _, at 552.

${ }^{135}$ Williamson, Governance, supra note _.

136 See, e.g., Oliver Hart, An Economist's Perspective on the Theory of the Firm, 89 Colum. L. Rev. 1757 (1989): 1757-74; Oliver Williamson, Markets AND HiERARCHIES 30, 78 (1975); Williamson, Governance, supra note _, at 241-42 (suggesting that unenforceability of contract clause prohibiting opportunistic behavior could make the firm a more efficient governance structure for long-term commercial relationships); Williamson, Economics, supra note _, at 559; Benjamin, Robert Crawford, and Armen Alchian, Vertical Integration, Appropriable Rents, and the Competitive Contracting Process, 21 J.L AND ECON. 297, 302-03 (1978). Scholars often use the term "contractual” to refer to any kind of (usually presupposed) exchange/market relationship. See Gordon Smith, Contracts as Organizations, 51 ARIz. L. REV. 1, n.63 (2009) (noting that when scholars refer to "relational contracts," they are often referring to non-legal dimensions of (continued next page)
} 
rists of the firm spoke of firms and markets almost interchangeably with employment and contracting. ${ }^{137}$ Coase suggested, for example, that when an entrepreneur wanted a long-term but flexible agreement, and did not want to work out important details ahead of time, the legal template of contract-which requires that parties specify their rights and obligations with some certainty upfrontwas unsuitable. In this case, the entrepreneur must use the employment relationship, or firm, which afforded the entrepreneur more open-ended authority. ${ }^{138}$ Coase's account thus restates the very reason judges and treatise writers in the $19^{\text {th }}$ century incorporated master-servant relations into contracts for labor services-to grant more discretionary control to the employer than that afforded by contract. $^{139}$

Also evocative of the intimate relationship between conceptions of the firm and employment, firm theorists have conceptualized the firm as a superior governance structure for coordinating a complex division of labor, or multilateral relations in production. Alchian and Demsetz, for example, suggest that firm production might be desired when production involved a complex division of labor, making it difficult to coordinate through a contract, which contemplated a bilateral relationship. Make or buy decisions would

exchange relations). C.f. Stewart Macaulay, Non-Contractual Relations in Business: A Preliminary Study, 28 Am. Soc. Rev. 55 (1963); Ian MacNeil, Contracts: Adjustment of Long-Term Economic Relations under Classical, Neoclassical, and Relational Contract Law, 72 Nw. U. L. REV. 854 (1978). Many theorists of the institutional structures for coordinating resources in production have complicated the binary firm-market taxonomy, proposing new governance forms, like "network," focusing more on informal dimensions of commercial relationships, and/or defining organizational forms in terms other than the legal relations that structure them. See, e.g., Gordon Smith, supra; Oliver Williamson, The ECONOMIC Institutions of CAPITALISM 16-18 (1985); Reinier Kraakman, The Durability of the Corporate Form, in THE Twenty-FIRST-Century FiRM: CHANGING Economic Organization in International Perspective 147 (Paul DiMaggio ed. 2001) (empahsizing the centrality of the corporate form even in networks).

137 See, e.g., Oliver Williamson, The Vertical Integration of Production: Market Failure Considerations, 61 AMER. ECON. REv. 112, 113-14 (1971). In discussing the putative trade-off between flexibility and calculability associated with firms and markets, respectively, Williamson argues that the firm offered the advantage of control (and thus greater calculability) through the employment relationship. See also OLIVER Williamson, MARKETS AND HiERARCHIES 78 (1975); Alchian and Demsetz, supra note _, at 783 (equating the capitalist "firm” with the "employer.") See generally Bodie, supra note

$\overline{138}^{\cdot}$ Coase, supra note _, at 391-392.

139 CHRISTOPHER L. TOMLINS, LAW, LABOR, AND IDEOLOGY IN THE EARLY AMERICAN REPUBLIC 230-31, 283-84 (1993). 
depend on how best to realize the advantages of cooperative production-production based on the joint use of inputs. ${ }^{140}$ They reject Coase's notion that the command relation defines the firm; however, their analysis of how to reduce shirking and meter individual productivity suggests that the firm is more efficient when most input owners contribute primarily the ability to work and not other assets. $^{141}$

Robert Gibbons has focused on property ownership to illustrate the firm-employment connection: "making” an input to production entails purchasing labor effort and the other supplies needed to make the input from separate suppliers-the supplier of labor effort (the employee) does not possess the other supplies. A "buy" decision means purchasing labor effort and complementary supplies from a supplier who possesses both, and who has already combined them into a completed input for sale. ${ }^{142}$ In major economic theories of the firm, employment largely distinguishes the firm from the market. ${ }^{143}$

\section{The Firm and the Legal Tests}

The industrial firm was the empirical model for Coase's theory of the firm and the legal tests for employment status. As both bear its imprint, it should be unsurprising that the firm-employment connection is immanent in the legal tests for employment status. For example, under the legal tests, unskilled workers are more likely to be employees than independent contractors. Hiring unskilled workers, particularly in an economy where labor supply exceeds demand, also suggests the entrepreneur is "making" a production input. The entrepreneur expends few resources to search the market for no-frill labor effort. Unskilled work and the entrepreneur's ownership of the tools of production also suggest a "make" deci-

140 Armen A. Alchian and Harold Demsetz, Production, Information Costs, and Economic Organization, 62 AM. ECON. REv. 777 (1972); see also Bodie, supra note _, at 39.

${ }^{141}$ Alchian and Demsetz, supra note _.

142 Robert Gibbons, Firms (and Other Relationships), in THE TwENTY-FIRSTCentury Firm: Changing Economic Organization in International Perspective, 186, 188-89 (Paul DiMaggio ed. 2001).

${ }^{143}$ See Matthew Bodie's Participating as a Theory of Employment, 89 NotRE DAME L. REV. 661 (2014). 
sion under Gibbon's theory: the "upstream party"-the employee-contributes effort, not effort plus assets. ${ }^{144}$ Under a transaction cost theory of the firm, supplying the tools of production and requiring workers to undergo in-house training augur firm production as well. These elements suggest asset specificity and high uncertainty regarding whether the entrepreneur will find labor possessing the desired knowledge on the market. Whether the supplier sells its services to others, or "whether or not the one employed is engaged in a distinct occupation or business," 145 also measure asset specificity and uncertainty. Similarly, under Gibbons' theory, an upstream party in a market with one buyer is an employee. Likewise, under Coase and Williamson's theory, firms would be expected to incur costs in ex post monitoring and sanctions in organizing production, but expect the entrepreneur who is contracting with independent suppliers to incur more of its costs in ex ante negotiations. Consistent with this expectation, supervision of the work and a right to discipline the worker are evidence of employment under the legal tests. The extent to which the work is part of the alleged employer's "regular business" more explicitly asks whether the worker is part of a firm, and therefore more likely an employee. ${ }^{146}$

\section{Destabilizing the Firm: The FedEx Enterprise as "Market"}

Due to the close relationship between socio-legal conceptions of the firm and employment, the tension between master-servant authority and contract within employment tends to destabilize the conventional boundary between firms and markets. As conceived by major theories of the firm, contractual relations in the market tend to be direct, bilateral, discrete, and putatively equal. Likewise, relations of production within a firm tend to be hierarchical, multilateral, and indefinite. The tension between bargaining and producing in employment reappears as a tension within the firm: employment as a contract is direct and bilateral, but employment is

\footnotetext{
144 Gibbons, supra note _.

145 Restatement (SECOND) OF Agency § 220(2) (1958).

${ }^{146} I d$.
} 
also the legal rationale for the firm's centralized control over indirect and multilateral relations in production. ${ }^{147}$

\section{Transforming FedEx into a Market}

Within the terms of major firm theories, like those of Coase, Williamson, Gibbons, and Alchian and Demsetz, FedEx is clearly making delivery services, not going to the market to buy them.

FedEx does not incur costs in searching the market for contractors with certain skills, experience, and equipment. ${ }^{148}$ It hires unskilled workers, who furnish no specialized assets, through a standardized application. ${ }^{149}$ Likewise, FedEx does not incur costs in negotiating or drafting a contract, given drivers sign a standardized, non-negotiable agreement. The required training and FedEx's provision of the tools of work also reflect asset specificity. By hiring unskilled workers and training them, FedEx minimized the risk that the experience and skill required for the job might be unavailable on the market, particularly given that FedEx was the only buyer. Instead, FedEx incurred costs in training, monitoring, and disciplining workers.

FedEx's control over delivery routes and daily workloads-its control over the initial route assignment, its monitoring of business volume, its frequent adjustment of route and package assignments-reveals a firm directing resources through fiat as it determines an efficient division of labor. ${ }^{150}$ The price mechanism is not determining the drivers' business volume. The route assignment also suggests firm production due to its high asset specificity from the driver's perspective. To receive a route, the driver must first make costly, “durable, transaction-specific investments," 151 or in-

${ }^{147}$ See Alchian and Demsetz, supra note _, at 794 (firm production involves "central common party to a set of bilateral contracts," which "facilitates efficient organization of the joint inputs").

${ }^{148}$ See Coase, supra note .

${ }^{149}$ Under Gibbons' theory, FedEx is purchasing labor alone from the drivers, not labor plus assets. FedEx is the only buyer on the market for these services, and the drivers sell only to FedEx. They do not own and control assets useful in the production of other goods or services. Gibbons, supra note _,

${ }^{150}$ See Coase, supra note _; Alchian and Demsetz, supra note _.

${ }^{151}$ See Williamson, Economics, supra note _. 
vest in resources, like a FedEx vehicle and training, that are difficult to redeploy to other uses. ${ }^{152}$

Nor did FedEx expose itself to uncertainty as to the price it supposedly pays for its delivery services: FedEx pre-determined its labor costs. Similarly, the company absorbed most of the risk of cost increases in non-labor inputs to production. While it externalized some production costs onto drivers, like fuel and vehicle maintenance, FedEx also assisted drivers with these costs. Further, FedEx realized economies of scale, for instance, in purchasing insurance for drivers. In sum, FedEx did not go to the market, repeatedly, to acquire the same service-a service for which it is the only buyer-from thousands of different independent suppliers. Regarding the proposed trade-off the firm offered between flexibility and calculability, FedEx left nothing to chance.

However, the contradiction between master-servant authority and contract enabled FedEx and the courts to transform a firm, as conceived by major economic theories of the firm, into a market. The IC decisions masked "make" decisions_-FedEx's purchase of labor effort-as "buy” decisions-FedEx's purchase of labor, labor effort absorbed and transmuted into a completed service. Thus, the IC decisions reinterpret performance evaluations and disciplinary action against the drivers as contractual negotiations between the drivers and FedEx. Supervision and ex post correction, characteristic of a firm transaction, become the activities of ex ante information gathering and negotiation, indicative of a market transaction. $^{153}$ Judge Miller, following FedEx's cues, suggested training drivers was a cost to FedEx of transacting on the market-a "buy" decision. It was a "precondition" to contracting, an asset drivers brought with them to the bargaining table. In interpreting FedEx's cancellation of a driver's otherwise automatic contract renewal as an aborted negotiation rather than an employee termination, the IC decisions also depicted what resembled a firm under economic

152 Drivers were not allowed to use their trucks for other commercial purposes during the 45-55 hours they were dedicated to FedEx. Outside of these hours, drivers could use the trucks for other purposes so long as they removed or covered all FedEx markings. FHD, 563 F.3d 492.

153 The drivers' pay formula also suggested they produced delivery services in a firm, not a market. The formula was based primarily on the time drivers committed to FedEx, not by project. It included seniority bonuses. FedEx also paid bonuses based on the collective performance of workers at a terminal. Kansas decision, 734 F.Supp.2d 557. 
theory as a market. A decision to cancel a driver's automatic contract renewal became an ex ante decision not to contract in the market, a decision not to engage in, "repeat business." ${ }^{154}$ Returning the example regarding the driver promotions to oversee more than one route, FedEx, not the price mechanism, is directing resources in production. The drivers' so-called “business expansion," looks very much like a firm's promotion of a driver up the internal job ladder. FedEx is coordinating hierarchical relations in production. FedEx and the IC decisions, however, suggested the decentralized market conferred the opportunity, rather than FedEx.

\section{Shift Replacements or Entrepreneurialism?}

FedEx and the IC decisions engaged the ambiguity between contracting and producing not only to redefine relations between FedEx and each driver, but also to redefine relations among drivers. In doing so, it dissolved the FedEx bureaucracy into a nexus of contracts. Multilateral cooperation among coworkers in production merged into bilateral relations between contracting parties in the market.

FedEx and the courts ruling in its favor argued that the drivers were entrepreneurs, because they could "hire" others to perform their work for them. Drivers could take advantage of expanding business volume on their routes by hiring multiple drivers or decide not to work at all. The courts and FedEx contended the latter was "not involved" in any of these transactions between one driver and another. ${ }^{155}$ However, any replacement and extra drivers must already have formed a work relationship with FedEx: they must undergo the required orientation, drug screening, road test, and agree to follow all the rules in the written agreement. Moreover, FedEx could still disapprove of anyone a driver wanted to hire. ${ }^{156}$ In other words, drivers could "hire" their coworkers.

Unsurprisingly, drivers usually used replacements when they needed a day off for illness or another reason. Or, they rented an extra truck and used one of FedEx's temporary drivers during the

154 Kansas decision, 734 F.Supp.2d at 595 (quoting Home Design, Inc. v. Kansas Dep't of Human Res., 27 Kan.App.2d 242, 247(2000).

155

156 
holiday season, when they needed the help to complete their assigned deliveries. This looks very much like having a coworker cover a shift for you, or getting a coworker to help you with your assigned work. However, the courts ruling for FedEx reinterpreted the company's centralized control over a complex division of labor in production as the drivers bargaining with one another in the market. ${ }^{157}$ Multilateral cooperation among drivers, as they worked under FedEx's supervision and control, became bilateral contracts between drivers in a decentralized market. Producing became contracting, and the fiat of the entrepreneur became the price mechanism.

Through the interpretation of shift replacements as incidents of contracting rather than producing, the MDL court also negated another factor probative of employment under the applicable legal test: the extent of the putative employer's control over the worker's schedule. Judge Miller acknowledged that FedEx tightly controlled drivers' schedules. Drivers had to arrive within a certain window in the morning-after the packages became available but early enough to complete the 9.5-11 hours of work FedEx assigned per day. They had to complete deliveries by a certain time in the evening and meet windows negotiated by FedEx for certain customers. Judge Miller argued, however, “Contractors' ability to hire assistants and replacement drivers, though, even under FedEx's approval requirements, allows them to have complete freedom in their schedules.” 158

3. From Firm to Market, From Bureaucracy to Nexus of Contracts

In fact, Judge Miller took the interpretation of shift replacements as an incidence of bargaining in the market rather than producing within a firm to a nonsensical extreme. The judge argued that FedEx indeed controlled and monitored virtually every detail of the drivers' work, from their schedules to their appearance to how they drove, kept records, handled packages, and interacted with customers. He noted that all of this normally would be evidence of employment under the governing legal test. But, he ar-

\footnotetext{
157

${ }^{158}$ Kansas decision, 734 F.Supp.2d at 591 (emphasis added).
} 
gued that here, it was not, because the drivers were not "personally" subject to any of these controls: FedEx controlled the positions but not the drivers. ${ }^{159}$

This is the very definition of bureaucracy. The FedEx enterprise resembled not just any firm as might be faintly adumbrated by economic theory: it resembled the consummate firm-a bureaucracy as conceptualized by Max Weber. ${ }^{160}$ The more the allocation, pacing, and direction of the work, as well as the skill and knowledge of the work, is embedded in the machine ${ }^{161}$-here the FedEx logistics system, and the more closely it's monitored, the more indifferent the firm becomes to whether it's Mary or Lee sitting in the delivery truck. The drivers are interchangeable. But this separation of the person from the position reveals a bureaucracythe consummate expression of a firm. ${ }^{162}$

Another dimension of the tension between master-servant status relations and contract comes to the fore here: As a masterservant relationship, employment is personal. As a contract, it is impersonal and presumably assignable. Here the court construes the fungibility of drivers as evidence that the relationship is impersonal-the kind of arms-length relationship found in the market. The drivers' interchangeability among standardized routines in a tightly integrated operation becomes evidence of FedEx's lack of control over their work. ${ }^{163}$

This exploitation of the tension between master-servant authority and contract not only redefines a firm as a market, but thwarts the policy purposes of collective bargaining and minimum wage law: The impersonality of bureaucracy-its indifference to the personal characteristics of those filling its slots-was possible precisely because the drivers were interchangeable, low-skilled workers. The very evidence that suggested their status as workers with little bargaining power-workers within the contemplated

\footnotetext{
${ }^{159}$ Id. at 596.

160 MAX WeBER, ECONOMY AND SOCIETY: AN OUtLINE OF INTERPRETATIVE Sociology 988 (Guenther Roth \& Claus Wittich eds., Univ. of Cal. Press 1978) (1922).

${ }^{161} \mathrm{Id}$. at 1395 .

162 Id. at 218-19.

163 Another dimension of the tension between master-servant status relations and contract comes to the fore here: As a master-servant relationship, employment is personal. As a contract, it is impersonal and presumably assignable. Here the court construes the fungibility of drivers as evidence that the relationship is impersonal-the kind of armslength relationship found in the market.
} 
scope of the NLRA and minimum wage and hour law-became evidence of independent contracting. The drivers' fungibility, their disposability, became evidence of their autonomy. The more that drivers were "small cog[s] in a ceaselessly moving mechanism which prescribes...an essentially fixed route of march," ${ }^{64}$ the more they looked like entrepreneurs. ${ }^{165}$

Judge Miller's association of driver autonomy with FedEx's purported indifference to who drove its trucks is belied also by FedEx's bodily inspection of drivers. Drivers had to submit to physical invasions not associated with civilian independent contracting-periodic drug screenings and physical examinations, and for some drivers, strength tests. These criteria for the job, as well as the driving record and criminal background check, could not be assigned from one body to another.

The IC decisions evoke Weber's comment about capitalist work:

The private enterprise system transforms into objects of 'labor market transactions' even those personal and authoritarianhierarchical relations which actually exist in the capitalist enterprise. While the authoritarian relationships are thus drained of all normal sentimental content, authoritarian constraint not only continues but, at least under certain circumstances, even increases. $^{166}$

\footnotetext{
${ }^{164} I d$.

165 Unsurprisingly, the case records reveal few scant instances where drivers availed themselves of the fabled entrepreneurial opportunity. In FHD, only one driver-a multiple-route driver-used his truck for a commercial purpose apart from serving FedEx. Three out of thirty-three drivers held multiple-routes, and two of these drivers relied on spouses to help with delivery volume. Not a single driver hired a full-time substitute. Drivers used substitute drivers only for illness or vacation. Further they usually selected substitute and extra drivers from a pool of replacement drivers FedEx made available for that purpose.

The MDL record indicated that drivers rarely hired full-time substitutes or supplemental drivers. Shift replacements appeared to cost drivers money rather than increase their earnings. See Greenhouse, supra note _. It is unclear the extent to which drivers at other terminals created independent businesses, but evidence is sparse. Foust 2005; Wishnia 2012; Grella 2009; Greenhouse, supra note _.

Regardless, the IC decisions are unable to explain why these opportunities are "entrepreneurial,” and not those available to a resourceful and smart employee.

166 WEBER, supra note _, at 731.
} 
The courts conflate the depersonalization of bureaucratic domination with the purported impersonality and autonomy of the market.

\section{The Legitimacy of the Firm}

Classic theories of the firm have not always explained firm boundaries very well. ${ }^{167}$ Financialization, globalization, technological advances, and other economic changes often uncouple governance types from their theorized costs and advantages. The theories have not provided a refutable explanation for today's buyer-driven supply chains, for example. ${ }^{168}$ These tend to centralize decisionmaking across firms. Other forms of production decentralize decision-making within firms. Classic theories of the firm tend to share the major flaw of assuming that the boundaries of the business form will coincide with the boundaries of the productive enterprise. The FedEx cases present another counterexample.

Nonetheless, in trying to provide an account for the firm's existence, theories of the firm also, implicitly, provide a legitimating account of the firm as a business form. Classic theories of the firm, like those expostulated by Coase and Williamson, ground the social legitimacy of the corporation in the production of goods and services: The warrant for the corporation is its ongoing coordination of a productive enterprise. In this regard, classic theories of the firm stand in counterpoise to theories that promote the corpora-

${ }^{167}$ For instance, Williamson's theory that differences between contracting and agency costs could explain make or buy decisions did not explain mergers and acquisitions in the 1980s. Charles Perrow, Economic Theories of Organization, 15 THEORY \& SOC’y 11 (1986).

${ }^{168}$ Non-property relations do not necessarily impose greater information costs than firms today. Communications and logistics technology have improved information flow across proprietary firm boundaries. Advanced technology also helps to reduce the metering of individual productivity across property lines in buyer-driven supply chains. Further, market position enables powerful buyer-firms to avoid the trade-off between control and the risk of decreases in product demand. Wal-Mart controls suppliers via its monopsony position. The company wants a flexible relationship with supplier firms akin to atwill employment. It uses market power rather than property ownership and employment to achieve this control. By de-integrating or refusing to integrate, large downstream firms can avoid liability, public scrutiny, and do not have to buy or maintain costly plant and equipment. See also Mark Granovetter. Economic Action and Social Structure: The Problem of Embeddedness, 91 AM. J. OF Soc. 481 (1985). 
tion as a "nexus of contracts," a "bundle of assets," or a tool for financial speculation, accounting manipulation, and regulatory evasion. ${ }^{169}$ As FedEx and the courts redefine the distinction between firms and markets, they redefine the appropriate relationship between the corporate form and the productive enterprise. ${ }^{170}$

In trying to explain the existence of firms, theories of the firm implicitly provide a legitimating account of the business form. Classic theories of the firm, like those expostulated by Coase and Williamson, grounded the social legitimacy of the corporation in the efficient production of goods and services. In redefining the FedEx work relationship as market production rather than firm production, the IC decisions reject this conception. They find company with those promoting the corporation as a tool for financial speculation, accounting manipulation, and regulatory evasion.

\section{Technology and Service Work}

Advances in technology and distinctions between service work and industrial manufacturing are two sources of institutional disruption in contemporary work relations. This section hypothesizes that these contributed to making salient the ambiguity between bargaining and producing in the FedEx disputes.

The FedEx bureaucracy is relatively invisible compared to the bureaucracy of an industrial manufacturing enterprise. The advanced logistics and communications technology that FedEx uses replaces the heavy integrated machinery and constant eye of the

169 Paul DiMaggio, Introduction: Making Sense of the Contemporary Firm and Prefiguring Its Future, in THE TwENTY-FIRST-CENTURY FIRM: CHANGING ECONOMIC Organization in International Perspective 3 (Paul DiMaggio ed., 2011). Gerald F. Davis, Managed by the Markets: How Finance Reshaped America (2009). Michael C. Jensen \& William H. Meckling, Theory of the Firm: Managerial Behavior, Agency Costs and Ownership Structure, 3 J. OF FIN. ECON. 305 (1976). Scholars generally use "nexus of contracts" as a theory of firm ownership and control, a hypothesis about relationships among owners, financiers, and management, rather than relationships among workers and management. Id. The article suggests, however, that the IC decisions offer a nexus of contracts theory of the firm based on relationships between workers and management.

170 See e.g., Alfred D. Chandler, The Visible Hand: The Managerial REVOLUTION IN AMERICAN Business (1977). See also Roy, supra note _ (refuting Chandler's efficiency theory as explanation for rise of large, integrated firms in the United States); Mark J. Roe, Strong Managers, Weak Owners: The Political Roots of AMERICAN CORPORATE FINANCE (1994). 
foreman typical of industrial manufacturing. FedEx organizes, directs, and paces the work largely through the former. For instance, barcode technology enables FedEx to monitor drivers' locations and delivery times. The control is relatively invisible.

Distinctions between industrial manufacturing and service work may also have played a role. The production of FedEx delivery services takes place not in a factory, and not only in FedEx terminals, but along thousands of miles of roads, and in the doorways of millions of residences and businesses. Production and consumption occur simultaneously in service work (i.e., the delivery driver produces the service as the costumer consumes it).

FedEx did not accomplish its direction of resources through gears and conveyer belts in a factory. It accomplished its fiat, its centralized control over a multilateral division of labor in production, through logistics and communications technology, and over an enormous geographic space not dedicated to FedEx production alone. To the IC courts, the FedEx bureaucracy appeared as a nexus of bilateral contracts among drivers in a sprawling market.

It is unlikely that any court would find that pre-specifying and embedding the work process in machinery is evidence of independent contracting-evidence that the alleged employer is not controlling the means of the work. However, the IC decisions, particularly Judge Miller, fail to appreciate the logistics machine of FedEx. FedEx's control over drivers through sophisticated technology appeared as freedom.

6. Institutional Work: Contract as Bilateral, Direct, and Exclusive

To flatten the FedEx bureaucracy into a "nexus of contracts," 171 the IC decisions perform institutional work. In particular, the decisions invoked an institutional features associated with contract relations: the contract as a bilateral, direct, and exclusive relationship. For instance the FHD majority emphasized that FedEx was not involved in the relationship between drivers and substitutes, extra drivers, and helpers: "[C]ontractors have the ability to

${ }^{171}$ Eugene F. Fama and Michael C. Jensen, Separation of Ownership and Control, 26 J. L. \& ECON. 301 (1983); DAVIS, supra note _. 
hire others without FedEx's participation," 172 and "substitutes and helpers have been hired without FedEx's involvement." 173 The IC decisions also characterized the promoted driver's supervision of other FedEx drivers as a distinct employment relationship in which FedEx was uninvolved.

By emphasizing the contract as direct, bilateral, and exclusive, the courts transformed multilateral relations among coworkers in the productive process into bilateral contracts in the market. The work of FedEx drivers is deeply embedded in a logistics system and managerial hierarchy as imperious as the assembly line of an industrial firm. However, by constructing the relationships among drivers as contractual relations that excluded FedEx, the decisions seem to make the FedEx logistics machine and bureaucracy disappear. In rendering the integrated enterprise of FedEx largely invisible, this institutional work created the illusion of independent business activity among drivers. ${ }^{174}$

\section{Contractual Ends or the Manner of Performance?}

This section examines how the IC decisions dealt with the second interpretative ambiguity in the employment contract identified in Part II-the ambiguity between contractual duties and the way they are performed. It shows that this ambiguity, like the ambiguity between the activities of bargaining and producing, created discord among courts considering the employment status of FedEx drivers. It also shows another way in which the IC decisions constructed the written contract as a marker of non-employment, ${ }^{175}$ apart from

\footnotetext{
172 FHD, 563 F.3d at 502.

${ }^{173} \mathrm{Id}$. at 503.

${ }^{174}$ A driver's permission to sell a route to another FedEx driver provided opportunity to profit, albeit in a one-time sell, for a few drivers. In the FedEx Home Delivery dispute, most new drivers received routes for free from FedEx, limiting the emergence of a viable secondary market in FedEx jobs. FHD NLRB Reg. Dir. decision 2006. Most who quit their positions at FedEx did not sell their routes, and terminated drivers were not allowed to sell them. Id. There is no evidence in any of the case records that any FedEx driver created a business model out of trading FedEx jobs. It is also unclear why permission to sell one's job is evidence that the position affords entrepreneurial opportunity.

175 For a more detailed discussion of how this ambiguity engenders inconsistency in legal disputes over employment status, see Julia Tomassetti, The Contracting/Producing Ambiguity and the Collapse of the Means/ends Distinction in Employment, 66 S.C. L. Rev. 315 (2014).
} 
positioning it as a temporal barrier between bargaining and producing.

As explained in Part II, the law's attempt to assimilate masterservant relations to contract produced a peculiar kind of contract in employment. Unlike other contracts, the employment contract gave one party a right to determine how the other party performed its contractual duties. The means-ends standard for employment status thus asks whether one party has a right to determine not only the contracted-for ends of the deal, but also the "means" of performing them. Parties may flex their muscles to insist that their contract include certain obligations. Yet neither has a right to control how the other performs those obligations. Distinguishing employment from independent contracting therefore depends on being able to distinguish between contractual duties and the manner of their performance, in order to evaluate whether one party is controlling the latter, or just the former. As explained in Part II, the problem is that the fusion of master-servant authority with contract makes the distinction between contractual duties and how they are performed. The employment contract collapses contractual formation and performance. The employer and employee do not consummate a contractual bargain and then proceed to perform it.

This conundrum puts the written agreement in an ambiguous position in employment status disputes. It permits two possible interpretations: (1) Does anything stated in a written agreement necessarily refer to a contractual obligation and not the manner of satisfying it? Therefore, if the alleged employer is not telling workers to do anything that is not in the contract, is it not controlling the work? Likewise, if the alleged employer is closely supervises the work, but only to ensure workers conform to contractual specifications, is it not controlling the work? (2) By contrast, are some things stated in the contract not really contractual duties-do they actually give one party has a right to determine how the other performs contractual duties or collapse the distinction?

The IC decisions take the first approach with respect to the Operating Agreement (OA) drivers signed with FedEx. Judge Miller and the D.C. Circuit find that anything stated in the written contract was a contractual duty, by virtue of its expression there. The written contract could not give one party has a right to control how the other performs a contractual duty. Therefore, because FedEx was not supervising and directing the work in any way that was 
inconsistent with or extraneous to the written contract, it was not their employer: it was not telling the drivers how to perform their contractual obligations, because these were the contractual obligations. The long, detailed OA (over seventy pages) purportedly exhausted FedEx's authority over drivers and described their relationship ex ante with reasonable certainty. The document drivers signed became an institutional marker of non-employment: it formed a firewall between producing and contracting, protecting the latter from contaminating the former, as it does in employment.

For example, Judge Miller repeatedly implied that the extensive elaboration of work in the OA established the precise bounds of FedEx's authority, and its lack of interest in controlling the work during production. ${ }^{176}$ He acknowledges that "[v]arious provisions of the Operating Agreement authorize FedEx to control the days of service, the contractor's daily workload, and certain time windows when pick-ups and deliveries must be made. These requirements weigh in favor of employee status..." He continues, however, by arguing that these requirements "are more suggestive of a results-oriented approach to management when viewed with the totality of circumstances. FedEx has contracted for the performance of certain work and has the right to require that the work be completed as agreed.”177

Both Judge Miller and the D.C. Circuit suggested that any supervision of the drivers to ensure that they were complying with specifications in the OA could not be evidence of employment: the company was not exercising extra-contractual discretion. FHD also interpreted the five-day workweek of industrial employment as more consistent with independent contracting than employment. It argued that FedEx did not control the means of the work, since "it is undisputed the contractors are only obligated to provide service five days a week." "178 Judge Miller also characterized features of the work typical of industrial employment as contractual undertakings by FedEx. Thus, required training was not weighty evidence of employment status, because the written agreement required FedEx to "familiarize" drivers with the service they would pro-

\footnotetext{
${ }^{176}$ See also supra Part IV.D.

177 Kansas decision, 734 F.Supp.2d at 589.

${ }^{178}$ FHD, 563 F.3d at 499 (emphasis added).
} 
vide. ${ }^{179}$ Also, with respect to assigning drivers 9-11 hours of work per day, five days a week, "FedEx is required to fulfill this obligation pursuant to the parties' agreement, so it isn't necessarily indicative of employee status.” 180

Likewise, the DC Circuit suggested that many work rules prespecified in the OA were not in this instance evidence of employment, because they were contractual obligations that described the service the drivers agreed to provide. The court acknowledged that in other delivery driver cases, including prior cases involving FedEx drivers, judges found certain features of work relevant to the question of employment status-rules regarding training, insurance, uniforms, grooming standards, vehicles, performance bonuses, the inability to turn down assignments, and the five-day workweek. The majority argued that, in this case, however, "those distinctions, though not irrelevant, reflect differences in the type of service the contractors are providing rather than differences in the employment relationship." 181

The most extreme example of using the ambiguity between contractual duties and their performance to negate evidence of employment under the legal tests involved Judge Miller's interpretation of the drivers' right to quit in the written contract. The judge noted that FedEx assigned each driver 9-11 hours of package deliveries per day, and that drivers had to delivery every package assigned to them that day. He acknowledged, "Requiring workers to accept assigned work weighs in favor of employee status." 182 However, he claimed, "contractors can terminate their contracts upon thirty days' notice, in which case, they would be relieved of any future work assignments.” The right to quit is evidence that the drivers are employees under the governing legal tests. By default, an employee can quit without incurring contractual liability. Because the OA states the driver's at-will right, however (modified only with a notice requirement), the court interprets it to negate not only this evidence of employment status, but also the evidence that FedEx has a right to assign daily workloads.

${ }^{179}$ Wells v. FedEx Ground Package Sys., 979 F.Supp.2d 1006, at *6 (E.D. Mo. 2013) (citing Operating Agreement drivers signed).

${ }^{180}$ Kansas decision, 734 F.Supp.2d at 590.

${ }^{181}$ FHD, 563 F.3d at 501.

${ }^{182}$ Kansas decision, 734 F.Supp.2d at 590. 
Other courts considering the employment status of FedEx drivers differed in resolving the ambiguity between contractual duties and their manner of performance. The $9^{\text {th }}$ Circuit, for example, found that the OA was not limited to stating only the results of the work, but that the agreement gave FedEx the (non-contract-like) right to control the drivers' work. ${ }^{183}$

From a doctrinal perspective grounded in the distinction between a contract and a master-servant relationship, the IC decisions are incorrect in their interpretation of the written document drivers signed. The OA does not specify the essential details of the bargain or limit the discretion of FedEx production. It reads much like a master-servant relationship. Some of its provisions nearly recite the legal definition of employment. For example, drivers agree to follow supervisory instructions ("cooperate with" FedEx employees). Some expressly give FedEx a right to determine the terms and conditions of work during the course of the work. For instance, drivers agree to follow whatever appearance and grooming standards FedEx might promulgate from "time to time," and to service a route as changed by FedEx from "time to time." Some provisions contemplate that FedEx will exercise ongoing discretion in its direction and supervision of the work. For example, drivers must complete work assigned daily.

Some of the contractual terms the IC decisions cite as evidence of the drivers' entrepreneurial opportunity are actually evidence of employment. Take the example of route assignments and daily assigned work. FedEx and the IC decisions contend that route assignments are evidence of entrepreneurial opportunity, because drivers could negotiate for a good route and had contracted-for property rights in their routes. Yet, FedEx did not commit contractually to a route assignment, however. It reserved the right to change a driver's service area unilaterally, upon a few days of notice. ${ }^{184}$ Further, drivers agree to deliver packages outside their service areas and to relinquish deliveries in their service areas to other drivers “as requested” by management. Drivers agreed to perform

183 Alexander v. FedEx Ground Package Sys., 765 F.3d 981, 989 (9th Cir. 2014) ("What matters is what the contract, in actual effect, allows or requires") (emphasis added). See also Slayman v. FedEx Ground Package Sys., 765 F.3d 1033, 1042 (9th Cir. 2014).

184 See, e.g., Coase, supra note _, at _ (entrepreneur's preference for avoiding ex ante specification of significant details of the relationship favors firm production). 
whatever work FedEx required each day. Judge Miller admitted as much, noting, "FedEx drivers typically are required to flex packages. Flexing is the daily expansion or contraction of a drivers' work area." ${ }^{185}$ He likewise acknowledged that payment was based on "expected daily work hours," 186 and that FedEx had authority to determine the days drivers must work. ${ }^{187}$

All of these contractual "ends" leave it up to FedEx to determine the quantity of work the drivers will actually provide and what they will earn for it. The terms reveal that the negotiation process regarding the drivers' services does not end upon signing the agreement. The drivers and FedEx never arrive at an agreement regarding the essential terms of a contractual bargain.

The contract did not limit FedEx's discretion; it simply deemed every exercise of discretion resembling the traditional prerogatives of an employer as consistent with the contract and an exercise of contract enforcement. While FedEx claimed that it could terminate a contract only upon a driver's breach, it reserved the authority to interpret whether drivers' satisfactorily complied with the agreement. $^{188}$

Many of the work rules the drivers contracted to follow required interpretation and implementation by supervisors. The "Standard of Service" the drivers agree to provide-the supposed "ends" of the work - is stated in broad terms that managers must fill out during the course of the work. To do so, managers used think manuals full of detailed policies that were generally unavailable to drivers. Managers also had discretion regarding what alleged breaches of the OA to document in drivers' files. Drivers had recourse to arbitration only after termination. While the OA required FedEx to give notice before terminating a driver, it could suspend a driver without notice. ${ }^{189}$

${ }^{185}$ Kansas decision, 734 F.Supp.2d at 569.

${ }^{186} I d$. at 568.

${ }^{187}$ Id. See also id. at 589 ("Various provisions of the Operating Agreement authorize FedEx to control the days of service, the contractor's daily workload, and certain time windows when pick-ups and deliveries must be made.”)

${ }^{188}$ Estrada at 334.

${ }^{189}$ In one decision, Judge Miller cited nine instances where Michigan terminal managers threatened to refuse bonus payments or terminate drivers for rule violations. In re FedEx Ground Package Sys., Inc., 273 F.R.D. 499 (N.D. Ind. 2010). 
Another court ruling on the drivers' employment status recognized the quantum dimension of the drivers' supposed contractual duties, arguing that the "right to interpret the OA and the other matters is in the sole hands of [FedEx]. By leaving such subjective interpretation to the discretion of management, the relationship between the [drivers] and [FedEx] ceases to be a partnership, metamorphasizing into a tightly controlled hierarchical employment model." ${ }^{190}$ In sum, the "OA is a brilliantly drafted contract creating the constraints of an employment relationship with [single-route drivers] in the guise of an independent contractor model."191 Where the IC decisions saw a congeries of equal parties in the market, this court saw a model of rational bureaucracy:

[The] lack of objective, precisely defined guidelines either reflects a totally disorganized business, which [FedEx] is certainly not, or a highly motivated, well organized entity, which it is, that utilizes control and order in order to meet its successful economic goals. ${ }^{192}$

We think of contracts as delineating discrete obligations between two parties. ${ }^{193}$ The FedEx contract, however, appears to describe the enterprise organization. The contract pre-specifies the work a little like an engineering blueprint. Its work directives deposit the drivers into a highly rationalized, tightly integrated productive process controlled from the top. ${ }^{194}$

190 Estrada trial ct. 2004, at *5.

191 Id. at *3.

192 Id. at $* 6$. The Kansas Supreme Court and 9th Circuit also interpret the significance of these contractual provisions in the opposite manner of the IC decisions. They suggest that an employer cannot transform the means of work into the ends of work merely by stating so in its contract.

193 See Judy Fudge, Fragmenting Work and Fragmenting Organizations: The Contract of Employment and the Scope of Labour Regulation, 44 Osgoode HaLL L. J. 609 (2006); Judy Fudge, The Legal Boundaries of the Employer, Precarious Workers, and Labour Protection, in BOUNDARIES AND FrontIERS OF LABOUR LAW: GOALS AND MEANS IN THE REgUlATION OF WORK 295 (Guy Davidov and Brian Langille eds., 2006); see also FREEDLAND, supra note , at 36-52.

${ }^{194}$ Even if many rules in the contract provide meaningful guidance, some courts still resist interpreting everything in the contract as a description of the ends of the work. Courts have been unwilling to construe rules involving uniforms, grooming, demeanor, and work schedules as consistent with independent contracting. See, e.g., Alexander. 
The following thought experiment seeks to illustrate how the interpretative ambiguities in employment make it possible for judges to reinterpret even traditional employment as independent contracting. ${ }^{195}$ It is also meant to illustrate the potential role of technology and service work in shaping the IC decisions-they make it easier to disguise the FedEx bureaucracy as a nexus of contracts in the market. Finally, the though experiment is meant to reveal how distant the image of the firm constructed in the IC decisions is from the firm as conceptualized by classic theories of the firm:

- You contract with the firm for a "proprietary right" to your assembly line workstation. You are responsible for rotating and inserting pins inside each widget that comes down the conveyor belt in a day. You have no set schedule, but the firm turns on machine at 7:30 am so you cannot begin before that. You can take breaks when you want, but the engineers control the speed of the machinery, and they have estimated how long it takes you to grab the widget, turn your wrist, pick up a pin, and insert it, and thus you will have 9.5-11 hours of work per day. You must work so as not to hold up the next station. We turn the machine off at 5:30 pm.

- You have entrepreneurial opportunity: You receive payment per each widget and pin, and depending on our customer demand, the machine will speed up and send more pins down per day. If it looks like you are falling behind, we will give some of your work to a coworker or install an automated widget rotator that will decrease your pay. But, we give you five days to present a plan to us showing how you can take advantage of this increased "business volume" by finding a coworker to help hand you the pins or purchasing an expensive widget rotator.

- You also "invest" in your business/workstation, because you are responsible for paying for the oil to keep that part of the conveyor belt moving. As long as all these implements meet the particular specifications we set, you can

${ }^{195}$ I thank Larry Solum and Noah Zatz for suggesting this thought experiment. 
buy them anywhere. Thus, you have the entrepreneurial opportunity to earn "profit” by finding cheap suppliers. ${ }^{196}$

- You can "hire" others to run your station, so long as they are coworkers or workers who we have already agreed to hire. You can expand your business if we allow you to manage a group of stations and hire coworkers to run them.

- A few times a year, a supervisor will stand next to you all day. Otherwise, we do not supervise. We do monitor "customer service," however, through sensors that measure your speed and accuracy.

\section{CONCLUSION}

The paper posed the following question: how are courts able to interpret what very much looks like a "typical" relationship between an employer and employee as a relationship between two independent firms? The answer is that the employment contract itself is contradictory. The law's attempt to render master-servant authority as a contract collapses the distinctions between contractual formation and performance, and, as a result, between the activities of bargaining and producing, and between the "ends" and "means" of the work. It enables courts to negate the importance of, or even reverse the meaning of, many of the factors probative of an employment relationship under the legal tests for employment status. It enables courts to redefine features of industrial employment, like the opportunity for a promotion or permission to have a coworker cover a shift for you, into evidence of entrepreneurial opportunity. It also destabilizes the distinction between firms and markets.

In the past, many social actors participated in institutionalizing employment as a somewhat intelligible relationship. They developed patterns of activity, media, norms, and organizations to represent employment in the industrial age. The institutional markers of industrial employment bore no necessary relation to the "means" or "ends" of the work, however. They were settlements. For a time, they submerged, but did not ultimately resolve, the contradiction

196 FedEx had argued that drivers had entrepreneurial opportunity because they could save money by locating cheap mechanics. 
between servitude and equality embedded within the employment contract.

Today, the contradictory nature of capitalist work is reemerging. Several changes appear to be causing the institutional disruption: a movement among firms to shift risks to workers, a reorientation of the economy around financial markets putting ever more pressure on profits, the growth of the service sector, and technological revolutions in logistics and communications. Institutional disruption forces judges to confront the contradictory complex of servitude and equality that defines employment. It prompts efforts to reconcile the tension between servitude and equality by constructing new institutional features to mark an employment relationship.

FedEx reorganized many of the conventional, institutional markers of industrial employment in the drivers' work. These were markers that had purported to separate contractual formation from performance in employment. In an industrial manufacturing firm, for example, human resources personnel might hire the worker and explain salary and benefits. Later, distinct personnel in a manufacturing division will probably supervise the worker on the factory floor. These organizational markers separated the productive process from the sorting of workers in the labor market and the contracting process. Courts differed on how to make sense of the FedEx disorganization and thus how to understand the drivers' work relationship with FedEx. In disorganizing these markers, FedEx enabled the contradiction within employment between masterservant authority and contract to resurface. As courts contend with the doctrinal manifestations of this contradiction, they work to reinstitutionalize employment as an intelligible relationship. The IC decisions worked to re-institutionalize what looks much like what scholars have referred to as standard employment-a direct, fulltime, long-term relationship between a worker and a large firm-as one of independent entrepreneurialism. By drawing upon the ambiguities embedded within the legal definition of employment, they transform employment into independent contracting, a firm into a market, and a bureaucracy into a nexus of contracts.

This paper elaborated on one aspect of the institutional work that the IC decisions perform to reconstruct employment as a meaningful relationship: the decisions construct the written agreement the drivers sign with FedEx as a marker of independent contracting. First, they deposited the written agreement as a temporal 
barrier between bargaining and producing. FedEx shifts the temporal site of the contract signing from its location in an industrial employment arrangement to transform features of the relationship that would ordinarily be evidence of employer control over the "means" of the work into control over the "ends. Secondly, the IC decisions draw on the ambiguity in employment between the articulation of contractual duties and how they are performed to construct the drivers' written agreement as an institutional marker of independent contracting. The IC courts maintain that the document stated only the contractual ends of the drivers' work, not its means. ${ }^{197}$ They suggest that such a lengthy contract must exhaust FedEx's authority over drivers. It signals that FedEx has not reserved the open-ended discretion in production that defines employment, that FedEx will not continue to bargain over the terms of work during production. The ostensibly detailed, upfront elaboration of the work appears to establish and protects a sphere of independent production.

The contract has a double structure as an institutional marker. On the one hand, it is an "extra-legal data” point. Judges are generally most comfortable with understanding their role as classificatory rather than constitutive. They would like employment to be a social relationship that is already "out there," which they then fit within a legal category, not a relationship they create by legal fiat. ${ }^{198}$ Thus, the contract has an extra-legal existence that judges recognize. For instance, parties to not need to intend to create legal relations to create an enforceable contract - they must intend to be in a deal, however. ${ }^{199}$ The contract also has a legal existence-it is a template and regulatory structure for private exchanges. ${ }^{200}$ Written documents purporting to be "contracts" do not necessarily meet

\footnotetext{
197

198 Zatz, Working at the Boundaries, supra note _, at 940.

${ }^{199}$ See Lucy v. Zehmer, 84 S.E.2d 516 (Va. Ct. App. 1954).

200 Roland Barthes' semiotics is helpful here. Barthes theorized the "sign" as a "symbol" plus the "signified" thing. The written contract in these decisions works a like Barthes' double exposure or revolving door explanation of a "myth.” In the myth, the signifier is a sign with a new signified. Here, the sign is the contract as legal template, and by interposing the contract as an institutional marker, the arbitrariness of the association between the sign-as-signifier (contract as legal template) and new signified (nonemployment) is submerged in the association between the signified and signifier in the sign. Roland Barthes, Mythologies (1972).
} 
the requirements of a binding legal contract. In the many disputes over employment status, however, by assuming the trappings of a legal template, the written agreement gains doctrinal and normative valence as a marker of non-employment.

If the legal tests are ambiguous, and if the very definition of employment is contradictory, what was the basis for the author's critique of the IC decisions? The paper argued that the decisions and their reasoning are wrong for reasons of doctrine, policy, and the legitimacy of the business form.

First, many of the elements in the governing tests that the courts either negate or even transform into evidence of independent contracting bear on what should be the ultimate doctrinal question: is the disputed relationship more like a contract or more like a master-servant relationship?

Secondly, this difference is relevant to the premise of most statutory work laws, including those at issue in the IC decisionsthe NLRA and wage and hour law. The premise of most statutory employment protections is that a systematic disparity in bargaining power between workers and employers warrants statutory intervention. To say that an employer has a "right" to control the work, from the perspective of contract doctrine, is simply an observation that the employer will tend to get its way in the continuing bargaining over the work, as the employer directs the work and the employee decides whether to quit or to follow the employer's direction. It means the employer has enough power to determine unspecified, but significant, terms of the bargain as the work relationship proceeds. Thus, the right to assign daily work is evidence of employment, because it indicates that one party has enough power to determine the quantity of labor the worker must provide for a given price. Several factors in the legal tests for employment status are relevant to the doctrinal and policy questions, including skill and the right to discipline the worker. They reflect whether one party continues to "bargain" over the terms of the work, and get its way, due to superior economic power. FHD and Judge Miller exploited the ambiguities in the employment contract to redefine control over production as equality in contracting.

For the same reasons, the paper is critical of the IC decision's construction of the written agreement the drivers sign as a marker of non-employment. As an institutional marker, the written agreement purports to deconstruct the coincidence of domination in pro- 
duction and independence in contracting that defines employment. This is, of course, what written contracts purport to do-separate the process of contractual formation from performance. Not every piece of paper with "agreement" on the front achieves this purpose, however. The drivers' agreement does not delimit separate moments of contracting and production and protect the latter from the former. Rather than describe fixed obligations between FedEx and each driver, the agreement deposits the drivers into a tightly integrated process of production controlled by FedEx. By its terms, the agreement gives FedEx a right to determine the essential terms of the bargain during the course of the work. The IC decisions allow FedEx to use the written agreement to write around not only the legal test for employment status, but also around the contractual requirements of consideration and definiteness.

Finally, the paper suggested that the decisions rationalize a corporation whose boundaries bear no relation to the efficient production of goods and services, but instead seem calculated to evade statutory work protections.

Two modest changes in judges' approach to employment status disputes would improve decision-making and restrict the tendency of judges hostile to statutory work protections. ${ }^{201}$ The first is already at hand:

(1) Use contract law. In determining whether a relationship is one of employment or independent contracting, the ultimate question courts are trying to get at is whether the relationship is more like an employment relationship or a contract. What distinguishes employment from other contracts involving acute power disparities is not the lopsidedness of specified terms. Employment entails a particular term giving one party open-ended authority. Courts could use principles from contract law involving consideration, definiteness, negotiation and closure, and good faith, to better get

201 The bifurcated analysis explained in the $3^{\text {rd }}$ Restatement of Employment Law would also much simplify and improve legal reasoning in employment status disputes. The Restatement recommends first looking at whether the alleged employer closely supervises the physical details of work. This is sufficient, but not necessary, to establish employment status. When the alleged employer does not exercise such control, which could be the case in unskilled work where supervision is unnecessary or in the case of certain professional employees like doctors, the court would looks to whether the alleged employer's control "effectively prevents the service provider from providing the services as an independent businessperson. RESTATEMENT 3D. OF EMPLOYMENT (2015). Under the Restatement, the FedEx drivers are clearly employees. 
at the distinction: Do the ex ante terms of the agreement include a quantity term? Or is it more like a master-servant relationship, where one party agrees to provide an indefinite amount of labor for a definite payment? Are the essential terms of the bargain being worked out in production? Is it an "agreement to agree" by design? Does the agreement by its terms afford so much discretion to one party that it could deprive the other of the benefit of the bargain? As noted, several factors in the tests for employment status are relevant to distinguishing contracts from master-servant relations.

(2) Use principles from major economic theories of the firm. ${ }^{202}$ In order for any test for employment status focusing on a worker's "entrepreneurial opportunity" to be useful, judges need some means of distinguishing entrepreneurial opportunity-or opportunity conferred by the market-from the opportunity an employee has within a firm. A firm theory approach might curb the tendency of some courts to find workers to be independent contractors so long as the workers retain a smidgen of discretion (which is always). For example, under a transaction cost approach considering the trade-off between flexibility and control, a court would focus on what calculability the alleged employer relinquished by turning to the market, not on what discretion the worker retained. ${ }^{203}$ This approach would also direct courts to look at the broader matrix of exchange and productive relations the parties inhabit: is there any other buyer on the market for the putative contractor's services, for instance? If not, it is probably an employment relationship. Several factors in the legal tests for employment status already bear on whether the relationship more resembles firm production or market production. ${ }^{204}$

\footnotetext{
202 See Matthew T. Bodie, Participation as a Theory of Employment, 89 NOTRE DAME L. REV. 661 (2013)

${ }^{203}$ California in effect incorporates the concept of "residual" cost from transaction cost economics. This is the cost of lost calculability to the non-integrated from relinquishing some control over production. California's agency test looks at whether the alleged employer retained “all necessary control” for its purposes. S.G. Borello \& Sons v. Dep’t of Indus.

Relations, 769 P.2d 399, 405 (Cal. 1989). This shifts the focus of the means-ends standard away from what discretion a worker retains and away from the intensity of work monitoring. It centers the inquiry on whether the alleged employer supervises enough to meet its goals. Under this test, workers engaged in simple manual tasks are generally employees despite low levels of supervision.

204 Statutory reforms that include less open-ended definitions of employment and require courts to consider statutory purpose would also help. Judge Miller found that some (continued next page)
} 
Both of these solutions are limited. The first is dependent on the clarity of contract law. The second depends on our ability to distinguish firms from markets. It is not likely to work well when dealing with disputes over work arrangements less clear than the FedEx relationship. Much innovative research on contemporary arrangements for production rejects the firm-market binary. Firm theory cannot be of much help then if employment law continues to insist on an employment-independent contractor binary.

The provisional solutions also would not solve the problem of ensuring that workers without employers could access rights and benefits. Unlike the FedEx drivers, many workers do not have clear employers that are capable of complying with the law. These include day laborers, migrant farm workers, and some home health aids. We need new governance solutions for these workers. ${ }^{205}$

The provisional solutions elide another issue. Even if enforced in full, the panoply of rights the law affords to workers are insufficient to curb a growing inequality, durable poverty, and other macroeconomic harms, or to ensure the individual has the opportunity to flourish as befits a human being and citizen. A minimum wage, for instance, is not a living wage.

Finally, the problem is not simply that some courts draw the line between employment and other relationships in the "wrong" place. The law's attempt to render master-servant authority as a contract creates challenges for all legal decision-makers, not just those inclined to rule in the employer's favor. The prescription to draw from this article is not that we need a better method to draw a dividing line. The institutions that generate the categories requiring this bordering are flawed, and we need bigger fixes. Two goals should be to improve worker bargaining power or the supply elasticity of labor ${ }^{206}$ and to decommodify labor effort. ${ }^{207}$ Only a radical

FedEx drivers were employees under state statutes with narrow exclusions for independent contractors. See Kansas decision, 734 F.Supp.2d at 694-95. Some jurisdictions recognize a category of "dependent contractors." Two other reforms would not depend on judges' aptitude in recognizing an employment relationship-increasing penalties and improving enforcement of existing laws.

205 See, e.g., Benjamin I. Sachs, Despite Preemption: Making Labor Law in Cities and States, 124 HARV. L. REV. 1153 (2010); Brishen Rogers, Toward Third-Party Liability for Wage Theft, 31 BeRKelEy J. EMP. \& LAB. L. 1 (2010).

206 The first might entail providing opportunities for individuals to withdraw their labor from the market when the price goes down, as do owners of other commodities. Several policies and proposals tend to increase the elasticity of the supply of labor effort: (continued next page) 
transformation in work relations will ultimately stabilize the legal identity of contemporary work. The interpretative ambiguities that result from trying to encase master-servant relations in contract are a manifestation of a deeper conflict: our aspirations to be capitalist yet democratic, to commodify human will but eschew human servitude, to reconcile liberty of contract with liberty of person.

living wages; expanded opportunities for education, re-skilling, child rearing, and selfsustenance; social drawing rights; and a minimum income. See SUPIOT REPORT.

207 An example would be to abolish employment and require that labor services be sold through contracts. See also Sachs, supra note _, for other proposals that would help restrict the exchange of human effort as a commodity. 